\title{
KEKERASAN ATAS NAMA AL-QUR'AN: \\ Penganuliran Ayat-ayat Damai dengan Ayat Pedang dan \\ Pengaruhnya dalam Formasi Fiqh Jihâd
}

\author{
Wardani \\ Jurusan Tafsir Hadis Fakultas Ushuluddin IAIN Antasari. \\ Jl. A. Yani Km 4,5 Banjarmasin. Email: mwardanibjm@gmail.com. \\ Diterima 14 Januari 2010/ Disetujui 15 Mei 2010
}

\begin{abstract}
Tulisan ini difokuskan berbicara tentang justifikasi kekerasan atas nama kitab suci Alquran, seperti yang pernah melatarbelakangi pemboman di Indonesia, terutama yang dilakukan oleh Imam Samudera. Justifikasi tersebut bertolak dari penganuliran (naskh) luar biasa terhadap keberlakuan ratusan "ayat-ayat damai" yang disebut sebagai "ayat kesabaran, pemberian maaf" atau "ayat rekonsiliasi" dengan hanya satu atau sedikit ayat yang disebut sebagai "ayat pedang". Status penganuliran luar biasa tersebut menjadi kontroversi yang tak berkesudahan di kalangan pakar ilmuilmu Alquran. Para ulama tidak hanya berpolemik dalam mengidentifikasi ayat mana yang disebut sebagai "ayat pedang" dan ada atau tidaknya penganuliran, melainkan juga jumlah ayat damai yang dianulir tersebut yang berkembang secara dramatis dalam sejarah yang panjang. Penganuliran tersebut bertolak dari penafsiran ayat-ayat damai secara tidak utuh, seperti pemahaman ayat yang tidak sesuai dengan konteks sesunggubnya dan penganuliran ayat-ayat teologis dan moral yang tidak. mungkin teranulir. Penganuliran tersebut berpengaruh besar dalam formasi fiqh jïhâd.
\end{abstract}

Kata-kunci: ayat pedang, penganuliran (naskh), figh jihad, dan kekerasan.

\section{Pendahuluan}

Dalam ilmu penafsiran Alquran, apa yang disebut sebagai teori penganuliran (naskh) ayat Alquran dengan ayat Alquran yang lain adalah salah satu persoalan yang sejak zaman klasik hingga modern tetap menjadi kontroversi yang tak kunjung berujung dan tetap memicu kontroversi. Persoalan ini masih menyisakan problem akut yang berakibat hingga sekarang dalam konteks justifikasi kekerasan berbasis Alquran. Di antara persoalan tersebut adalah jenis penganuliran yang unik, penganuliran ayat 
yang dikenal dengan "ayat pedang" terhadap banyak ayat damai lain secara bersamaan. Perkembangan jumlah ayat yang dianggap mansûkh berkembang dramatis, semula hanya kurang dari sepuluh berkembang hingga ratusan ayat selama kurun waktu yang lama. Padahal, para penulis naskh sendiri berbeda pendapat dalam mengidentifikasi ayat pedang tersebut.

Apa yang dimaksud dengan ayat pedang itu? Bagaimana pandangan ulama tentang penganuliran (naskh) ayat-ayat damai dengan ayat tersebut? Apa pengaruh penganuliran tersebut dalam legislasi Islam tentang jihââ?

\section{Asal-usul Istilah Ayat Pedang}

\section{Fase Abad Ke-2-3 H: Para Penulis Awal Naskh}

Pada fase ini, belum digunakan istilah "ayat pedang" (âyat al-sayf). Para penulis awal naskh hanya menyebutkan dianulirnya sejumlah ayat tertentu dengan ayat yang terdapat dalam sûrat Barầah. Qatâdah bin Di'âmah al-Saddûsî (w. 117 H/ 736 M) menjelaskan adanya ayat al-Qur'an yang berstatus luar biasa dengan membatalkan beberapa ayat al-Qur'an secara sekaligus. ${ }^{1}$ Qatâdah tidak menyebut secara eksplisit Q.9/113:5 sebagai ayat pedang, melainkan hanya ungkapan "dalam (sûrat) Barâ'ah" (fî Barầab). ${ }^{2}$ Ia hanya menggunakan metafora "pedang" untuk perintah perang dalam Q.9/113:29—-sebenarnya juga terkandung dalam Q.9/ 113:5-ketika menjelaskan ayat ini sebagai penganulir larangan berdebat dengan kalangan Abl al-Kitâb (Q.29/85:46). Perintah perang tersebut adalah dianggap lebih efektif, karena 'tidak ada 'debat' yang lebih keras daripada pedang" (lâ mujâdalah ashadd min al-sayff). ${ }^{3}$

\section{Fase Abad Ke-4 H: Penisbatan Ibn Abî Hâtim kepada 'Alî bin Abî Thâlib}

Istilah "ayat pedang" (âyat al-sayf) berkembang dalam tradisi Sunnî dan Syîah. Penelaah berikut juga menunjukkan perkembangan penggunaan

${ }^{1}$ Lihat Qatâdah, Kitâb al-Nâsikeh wa al-Mansûkh fî Kitâb Allâh Ta'âlâ, dalam Silsilah Kutub al-Nâsikh wa al-Mansûkh, ed. Hâtim Shâlih al-Dhâmin (Beirut: Mu'assasat al-Risâlah, 1998), h. 23, 33, 40-42, 45, 47, 48-50.

${ }^{2}$ Lihat, misalnya, Qatâdah, Kitâb al-Nâsikh..., h. 40, 41, 42, 45, 50.

${ }^{3}$ Qatâdah, Kitâb al-Nâsikh..., h. 45. 
istilah tersebut dalam literatur-literatur tafsir, naskh, dan fiqh. Dalam karya

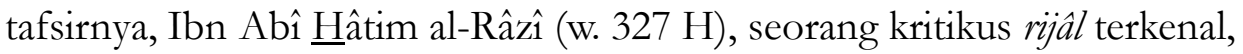
meriwayatkan bahwa istilah ini berasal dari 'Alî bin Abî Thâlib untuk menyebut Q.9/113:5:

Diberitakan kepada kami oleh ayahku (Abû Hâtim al-Râzî), diberitakan kepada kami oleh Ishââ bin Mûsâ al-Anshârî, ia berkata: Sufyân bin 'Uyaynah berkata: 'Alî bin Abî Thâlib berkata: "Nabi Muhammad saw. diutus dengan empat pedang, yaitu satu pedang ditujukan terhadap orang-orang musyrik dari kalangan Arab. Allah ta'âlâ berfirman: 'Bunuhlah orang-orang musyrik di mana pun kamu temui”" (Q.9/113:5). ${ }^{4}$

Dari segi otentisitas riwayat, para rawi yang terdiri dari Abû Muhammad 'Abd al-Rahmân (Ibn Abî Hâatim) (240-327 H), Abû Hâatim al-Râzî (195-277 H), Ishâq bin Mûsâ al-Anshârî (w. 244 H), dan Sufyân bin 'Uyaynah (107-198 H) adalah kredibel. ${ }^{5}$ Akan tetapi, Sufyân bin 'Uyaynah, mufassir penting abad ke-2 H/8 M yang mempengaruhi tokoh-tokoh sesudahnya seperti al-Thabarî, Abû Nu'aym al-Ishfahânî, Ibn Abî Hâtim,

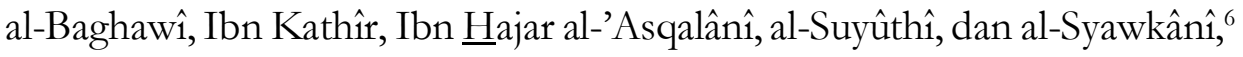
tidak bertemu langsung dan diperantari oleh dua orang (mu'dhal) hingga

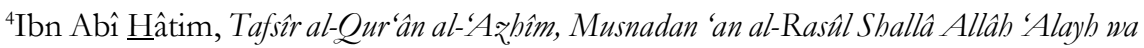
Sallam wa al-Shahâabah wa al-Tâbi’în, vol. 6, ed. As'ad Muhmmad al-Thayyib (Riyâdh: Maktabat Nizâr Mushthafâ al-Bâz, 1997/1417), h. 1752. Tentang posisinya dalam tingkatan (thabaqât) para mufassir, lihat Aḥmad bin Muhammad al-Adnarawî, Thabaqât al-Mufassirîn, vol. 2, ed. Sulaymân bin Shâlih al-Khizzî (Madinah: Maktbat al-'Ulûm wa al-Hikam, 1997), h. 65.

${ }^{5}$ Lihat Syams al-Dîn al-Dzahabî, Siyar A'lâm al-Nubalâ', vol. 13, ed. Shu'ayb al-Arna'ûth dan 'Alî Abû Zayd (Beirût: Mu'assasat al-Risâlah, 1983/1403), h. 263-269 (Ibn Abî Hâtim); As'ad Muhammad al-Thayyib, "Muqaddimah", dalam Ibn Abî Hâtim, Tafsîr al-Qur'ân al'Az̧him ..., h. 7-10 (Ibn Abî Hâatim); Siyar A'âm al-Nubalâ'..., vol. 13, h. 247-263 (Abû Hâtim); al-Mizzî, Tahdžbîb al-Kamâl..., vol. 24, ed. Bashshâr 'Awwâd Ma'rûf (Beirût: Mu'ssasat al-

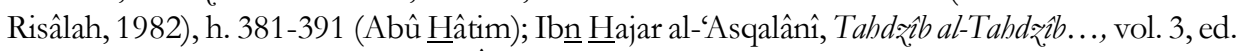
suntingan Ibrâhîm al-Zaybak dan 'Âdil Murshid (Beirût: Mu'assasat al-Risâlah, t.th.), h. 500502 (Abû Hâtim al-Râzî); vol. 1, 128 (Ishâq bin Mûsâ), al-Mizzî, Tahdž̂̉b al-Kamâl..., vol. 2, 480-483 (Ishâaq bin Mûsâ); vol. 2, h. 59-61 (Sufyân bin 'Uyaynah); Ibn Abî Hâtim al-Râzî, Kitâb al-Jark wa al-Ta'dûl, vol. 1 (Beirût: Dâr al-Fikr, t.th.), h. 32-54 (Sufyân bin 'Uyaynah).

${ }^{6}$ Dengan berpatokan pada riwayat-riwayat dalam karya tokoh-tokoh belakangan ini, tafsîr Sufyân bin 'Uyaynah telah direkonstruksi sebagai karya tafsîr utuh oleh Aḥmad Shâlih Mahâyirî. Lihat Claude Gilliot, "The Beginnings of Qur ânic Exegesis”, dalam Andrew Rippin (ed.), The Qur'an: Formative Interpretation (Great Britain: Ashagate, 1999), 16-17. Lihat riwayat

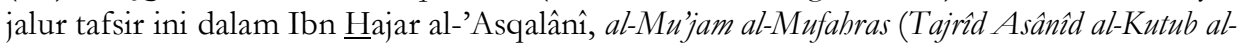
Masyhûrah wa al-Ajzầ al-Mantsûrah) (Beirût: Mu`assasat al-Risâlah, 1418 H/ 1998 M), h. 109. 
sampai ke 'Alî (w. 40 H/ 660 M). Jalur otentik tafsir Sufyân bin 'Uyaynah adalah yang diterimanya melalui Ibn Abî al-ㅂusayn - Ibn al-Thufayl (w. 44 $\mathrm{H})$ - 'Alî (40 H/ $660 \mathrm{M}) .^{7}$ Oleh karena itu, riwayat ini tidak otentik.

\section{Fase Abad Ke-5-7 H: Awal Penyebaran Istilah}

Pada abad awal abad ke-4 H, al-Nahhâs (w. 338 H/ 950 M) mulai menggunakan istilah âyat al-sayf untuk Q.9/113:5, meskipun masih menggunakan "dalam (surat) Barâ’ah" (fì Barâ'ab), ${ }^{8}$ ungkapan yang menjadi karakteristik para penulis awal, terutama Abû 'Ubayd yang menjadi sumber referensi utamanya, di samping sumber-sumber lain, seperti al-Thabarî (w. 310 H), al-Zajjâj (w. 311 H), Abû 'Ubaydah (w. 210 H), dan Ibn Qutaybah (w. 276 H). ${ }^{9}$ Uraian al-Nahhâs yang, menurut Khûrsyîd, mewakili "semua aliran tafsir" berpengaruh terhadap penulis-penulis sesudahnya, seperti Makkî al-Qaysî (w. 437 H), Ibn al-Jawzî (w. 597 H), al-Qurthubî (w. 671 H), dan al-Syâthibî (w. $790 \mathrm{H}) .^{10}$

Penyebaran istilah ayat pedang sesungguhnya dimulai sejak abad ke5 H. Dengan dimaksudkan sebagai handbook yang memuat daftar ayat-ayat nâsikh-mansûkh yang lengkap, Hibatullâh ibn Salâmah (w. 410 H/ 1019 M) menulis al-Nâsikh wa al-Mansûkh yang diakuinya disarikan dari 75 literatur naskh dan tafsir dari riwayat al-Kalbî (w. 146 H/ 763 M) dari Abû Shâlih (w. 222 H). ${ }^{11}$ Hibatullâh lebih intensif dibandingkan al-Nahhâs dalam menyebut âyat al-sayf sebagai ayat yang berstatus luar biasa yang menganulir

7Jalur riwayat yang otentik tentang tafsir yang berasal dari 'Alî bin Abî Thâlib ada tiga. Pertama, jalur Hishâm - Muhammad bin Sîrîn - 'Ubaydah al-Salmânî - 'Alî (jalur yang diterima al-Bukhârî). Kedua, Ibn Abî al-Husayn - Ibn al-Thufayl - 'Alî (jalur yang diterima dalam tafsir Sufyân bin 'Uyaynah). Ketiga, al-Zuhrî - 'Alî Zayn al-'Âbidîn - ㅂusayn - 'Alî (jalur paling otentik). Muhammad ㅂusayn al-Dzahabî, al-Tafsîr wa al-Mufassirûn, vol. 1 (Cairo: Maktabat Wahbah, 2000), h. 60.

${ }^{8}$ Abû Ja'far al-Nahhâs, al-Nâsikh wa al-Mansûkh..., h. 30, 37.

${ }^{9}$ Lihat lebih lanjut Sulaymân bin Ibrâhîm bin 'Abdullâh al-Lâhim, al-Nâsikeh wa alMansûkeh fì Kitâb Allâh 'Azza wa Jalla wa Ikhtilâf al- Ulamâ' fì Dzâlika Ta'lîf Abî Ja'far A hmad bin

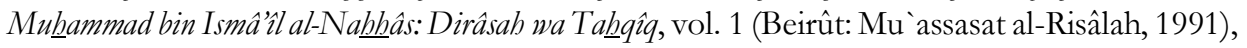
h. 131-173.

${ }^{10 ‘}$ Abdullâh Khûrshîd al-Birrî, al-Qur ân wa 'Ulumuh fí Mishr (20 H - 358 H) (Mesir: Dâr al-Ma'ârif, t.th.), h. 398-427; Sulaymân bin Ibrâhîm, al-Nâsikh wa al-Mansûkh..., h. 250-275.

${ }^{11}$ Hibatullâh ibn Salâmah, al-Nâsikh wa al-Mansûkh, margin al-Wahidî, Asbâb al-Nuzûul (Cairo: Maktabat al-Mutannabî, t.th.), h. 339-347. 
beberapa ayat lain. ${ }^{12}$ Dengan perkembangan ini, istilah tersebut digunakan intensif oleh para penulis belakangan, seperti al-Baghdâdî (w. 429 H/ 1037 M) ${ }^{13}$ dan Makkî al-Qaysî (w. 437 H/ 1045 M), ${ }^{14}$ Ibn Khuzaymah al-Fârisî (w. 490 H/ 1097 M), ${ }^{15}$ Ibn al-'Arabî (w. 543 H/ 1148 M), ${ }^{16}$ Ibn al-Jawzî (w. 597 H/ 1200 M), ${ }^{17}$ Shu'lah (w. 656 H/ 1258 M), ${ }^{18}$ dan Ibn al-Bârizî (w. 738 $\mathrm{H} / 1338 \mathrm{M}){ }^{19}$

\section{Fase Abad Ke-8 H: Pengembangan Ibn Katsîr}

Tafsir Ibn Abî Hâtim al-Râzî dianggap sebagai salah satu tafsir yang memuat penafsiran-penafsiran yang hilang yang berasal dari sahabat dan tâbi'ûn, seperti tafsir Sa'îd bin Jubayr (w. 95 H/ 713 M) dan Muqâtil bin Hayyân (w. 150 H/ 767 M). Di samping diringkas oleh al-Suyûthî dalam al-Durr al-Manthîr, tafsir ini menjadi salah satu sumber tafsir al-Thabarî dan Ibn Kathîr. ${ }^{20}$

Setelah mengutip riwayat 'Alî yang dikemukakan oleh Ibn Abî Hâtim al-Râzî dalam tafsirnya tentang Q.9/113:5 sebagai âyat al-sayf, sebagaimana dikemukakan di atas, Ibn Kathîr (w. 774 H), murid Ibn Taymîyah, mengembangkan penafsiran istilah tersebut sebagai berikut:

${ }^{12}$ Lihat, misalnya, Hibatullâh ibn Salâmah, al-Nâsikeh wa al-Mansûkh..., h. 66, 67, 96, 97, 103, 135-139, 145-147, 164-166. Lihat tabel klasifikasi ayat-ayat nâsikh dan mansûkh menurut Hibatullâh dalam Anwarul Haqq, Abrogation in the Koran (India: Methodist Publishing House, 1926).

${ }^{13}$ Lihat, misalnya, 'Abd al-Qâhir al-Baghdâdî, al-Nâsikh wa al-Mansûkh, ed. Hilmî Kâmil As'ad 'Abd al-Hâdî (Aman: Dâr al-'Adawî, t.th.), h. 79, 161, 221, 231.

${ }^{14}$ Lihat, misalnya, Makkî al-Qaysî, al-Îldhâh? li Nâsikh al-Qur'ân wa Mansûkßhih, ed. Ahmad Hasan Farhât (Jeddah: Dâr al-Manârah, 1986), h. 281, 286, 397.

${ }^{15}$ Lihat Ibn Khuzaymah al-Fârisî, al-Mûjaz fí al-Nâsikh wa al-Mansûkh (Cairo: al-Maktabah al-Azharîyah li al-Turâts, t.th.), h. 249-251.

${ }^{16}$ Lihat, misalnya, Ibn al-'Arabî, al-Nâsikeh wa al-Mansûkeh fî al-Qur'ân al-Karîm, anotasi alShaykh Zakarîyâ 'Umayrât (Beirût: Dâr al-Kutub al-'Ilmîyah, 2006), h. 129, 154, 155.

${ }^{17}$ Lihat, misalnya, Ibn al-Jawzî, Nawâsikh al-Qur'ân (Beirût: Dâr al-Kutub al-'Ilmîyah, t.th.), h. 53, 93, 131.

${ }^{18}$ Shu'lah, Shafwat al-Râsikh fì Tlm al-Mansûkh wa al-Nâsikh, ed. Muhammad Ibrâhîm 'Abd al-Rahmân Fâris (Ayn Shams: Maktabat al-Tsaqâfah al-Dînîyah, 1995), h. 100, 101, 103.

${ }^{19}$ Ibn al-Bârizî, Nâsikeh al-Qur'ân al-'Azîz. wa Mansûkhuh, dalam Silsilat Kutub al-Nâsikeh

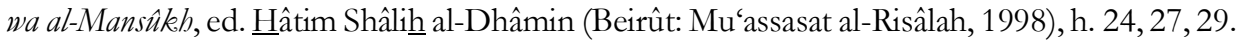

${ }^{20}$ As'ad Muhnmmad al-Thayyib, "Muqaddimah", dalam Ibn Abî Hâtim, Tafsîr al-Qur 'ân al-Azhîm..., h. 10-11. 
Saya kira bahwa pedang kedua adalah perang terhadap Abl al-Kitâb, karena Allah swt berfirman: "Perangilah orang-orang yang tidak beriman dengan Allah dan tidak pula dengan hari kiamat serta tidak mengharamkan apa yang telah diharamkan oleh Allah dan rasul-Nya dan tidak beragama dengan agama yang benar, yaitu orang-orang yang diberikan al-Kitâb hingga mereka mau membayar jizyah dengan patuh dan tunduk" (Q.9/113:29). Pedang ketiga adalah perang terhadap orang-orang munafik, seperti dalam firman-Nya: "Hai Nabi, berjihadlah melawan orang-orang kafir dan orang-orang munafik" (Q.9/113:73, Q.66/107:9). Pedang keempat adalah perang terhadap para pemberontak, seperti dalam firman-Nya: "Jika ada dua golongan dari orang-orang yang beriman berperang, damaikanlah antara keduanya. Jika salah satu di antara dua golongan tersebut berbuat aniaya terhadap golongan yang lain, perangilah golongan yang berbuat aniaya tersebut, sehingga golongan tersebut kembali kepada perintah Allah" (Q.49/106:9). ${ }^{21}$

Dari uraian para penulis naskh, bisa ditarik kesimpulan bahwa ayat pedang adalah ungkapan metaforis untuk menyebut suatu atau beberapa (sedikit) ayat al-Qur'an tertentu dengan ciri-ciri umum berikut:

a. Menggambarkan keadaan perang (state of war) yang disebabkan oleh pelanggaran perjanjian damai oleh sebagian orang-orang musyrik. dengan kaum muslim dan dianggap berisi "perintah (kewajiban)"22 untuk berperang secara paling tegas dan mutlak (ithlâq qatl al-kuffâr),

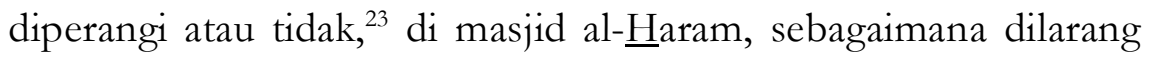
dalam Q.2/87:191, atau bukan, karena Nabi menyuruh Sâ̂̀d ibn al-

\footnotetext{
${ }^{21}$ Ibn Katsîr, Tafsîr Ibn Katsîr, vol. 2 (Beirût: Dâr al-Fikr, 1986), h. 227-228.

${ }^{22}$ Perintah tersebut umumnya ditafsirkan sebagai kewajiban. Lihat Abû Ja’far al-Nahhâs, al-Nâsikh wa al-Mansûkh..., h. 160. Tapi, sebenarnya, perintah tersebut hanya "kebolehan", karena perintah tersebut didahului oleh larangan (al-amr ba'd al-naby yufid al-ibâhaha). Patokan yang mirip adalah "perintah yang muncul setelah larangan hukumnya kembali ke keadaan

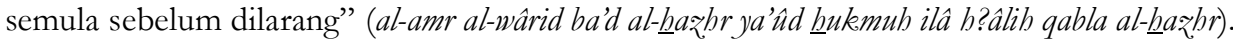
Dengan patokan ini, Khâlid 'Utsmân al-Sabt menganggap perintah ini bersifat wajib, karena perintah sebelum pelarang juga wajib. Lihat Khâlid 'Utsmân al-Sabt, Qawâ'id al-Tafsîr: Jam'an wa Dirâsatan, vol. 2 (Mesir: Dâr Ibn 'Affân, 1421 H), h. 487-488. Bandingkan dengan Ibn Jarîr alThabarî, Jâmi' al-Bayân 'an Ta 'wñl Ây al-Qur ân, vol. 14 ed. Mahnû̂d Muhammad Shâkir (Cairo:

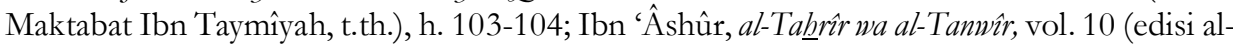
Dâr al-Tûnisìyah), h. 115.

${ }^{23}$ Lihat misalnya Ibn al-Jawzî, Nawâsikeh al-Qur'ân ..., h. 71.
} 
Makhzûmî dan Abû Barzah al-Aslamî (atau Zubayr bin 'Awwâm, menurut riwayat lain) untuk membunuh 'Abdullâh ibn Khat?al, seorang musyrik dari Banî Tamîm bin Ghâlib, yang sedang bergelantungan pada penutup Ka'bah pada peristiwa fath Makkah. ${ }^{24}$ Memerangi orang-orang musyrik dianggap oleh mayoritas ulama sebagai kewajiban yang harus dilaksanakan (fardh lâzim) di tempat mana pun. ${ }^{25}$ Dalam beberapa ayat yang diidentifikasi secara polemis sebagai ayat pedang, digunakan ungkapan tertentu (uqtulû, qâtilû, jâhid,

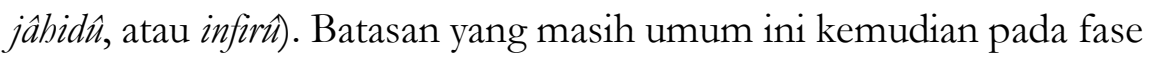
awal menyebabkan âyat al-sayf terkadang diidentikkan oleh sebagian penulis dengan ayat perintah membunuh (âyat al-qath), ayat perintah berperang (âyat al-qitẩ), atau setidaknya, ayat perintah memperlakukan kasar (âyat al-ghilįhah). ${ }^{26}$

b. Umumnya dimaksudkan memiliki status luar biasa dengan penganuliran unik ('ajîb al-naskh) secara sekaligus terhadap keberlakuan beberapa ayat damai (peace-verses), atau yang bermuatan perintah damai karena adanya perjanjian damai (âyât al-muhâdanab; âyât al-muwâda'ab), yang berisi pernyataan bahwa Nabi hanya sebagai pemberi peringatan, ${ }^{27}$ yang berisi perintah agar beliau bersabar atas kondisi yang tidak menyenangkan (âyât al-s?abr), ${ }^{28}$ memaafkan kesalahan orang lain, dan menghindari perdebatan dengan orang menolak keberadaan Tuhan (âyat al-'afw wa al-shafh). ${ }^{29}$ Penganuliran ayat-ayat ini, seperti tampak dari evolusi legislasi jihâd, dianggap lebih bersifat teologis sebagai sesuatu yang telah dijanjikan oleh Allah sebelumnya sebagai pertolongan dan kemenangan melalui perintah perang (Q.2/87:109, Q.37/56:174), ${ }^{30}$ karena kaum muslim akan terus ditindas, dan bersabar hanya menjadi pilihan menyulitkan ('ą̧m al-umûr) (Q.3/

${ }^{24}$ Shu'lah, Shafwat al-Râsikh..., h. 110.

${ }^{25}$ Makkî al-Qaysî, al-ÎIhâh..., h. 157-158.

${ }^{26}$ Istilah "perlakuan kasar" (ghilshah) tampaknya ditarik secara spesifik dari ungkapan

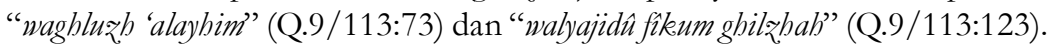

${ }^{27}$ Misalnya: Q.15/54:89, Q.19/44:39, Q.22/103:49, Q.35/43:24.

${ }^{28}$ Misalnya: Q.40/60:55, Q.50/34:39, Q.68/02:48.

${ }^{29}$ Misalnya: Q.53/23:29.

${ }^{30}$ Lihat, misalnya, al-Qaysî, al-Îldhâh..., h. 126; Ibn Katsîr, Tafsîr Ibn Katsîr..., vol. 1, h. 154-155; Ibn al-Jawzî, Nawâsikeh al-Qur'ân..., h. 212. 
89:186). ${ }^{31}$ Meskipun âyat al-qitâl memiliki status penganuliran ayatayat lain yang serupa, namun tidak sebanyak yang dianulir oleh âyat al-sayf, seperti tampak pada daftar Ibn al-Bârizî dan al-Fârisî. Hal itu, selain persoalan kronologi turun yang menjadi patokan penting yang menjadi representasi sikap final, juga karena âyat al-sayf dianggap sebagai representasi sikap paling tegas terhadap non-muslim, sehingga wajar kemudian muncul pendapat Ismâł̂̂l bin Uways (w. $220 \mathrm{H}$ ) tentang penganuliran antar âyat al-qitâl, yaitu Q.4/92:91 dianulir oleh Q.2/87:191 yang juga dianulir oleh Q.9/113:5. ${ }^{32}$ Finalitas dan ketegasan ini diidealisasikan oleh para penulis naskh, seperti tampak pada fiksasi naskh oleh Ibn al-'Arabî dalam bentuk kaedah, mencakup sikap muslim terhadap non-muslim di segala situasi apa pun.

c. Sasaran utama penerapan perintah tersebut adalah al-musyrikûn, alkuffâr, al-munâfiqûn, dan Ablal-Kitâb sebagai non-muslim, karena meski berbeda bentuk, semuanya dianggap sama-sama sebagai kufr (al-kufr millah wâhidah), baik melalui pengidentikkan syirk dan kufr maupun melalui penafsiran makna "fitnab" sebagai syirk (Q.2/87:193). Sasaran kedua adalah kaum muslim pemberontak (bughâh) dalam Q.49/106:9, meskipun penerapan "pedang" terhadap mereka menjadi kontroversi fiqh klasik, karena mereka tetap sebagai Abl al-Qiblah (muslim).

Ayat pedang adalah salah satu atau beberapa ayat berikut yang masih kontroversial:

a. Q.9/113:5.

Apabila sudah habis bulan-bulan suci itu, bunuhlah orang-orang musyrik itu di mana saja kamu jumpai, tangkaplah, dan kepunglah mereka dan intailah di tempat pengintaian. Jika mereka bertaubat, mendirikan shalat, dan menunaikan zakat, berilah kebebasan kepada mereka untuk berjalan. Sesungguhnya Allah Maha Pengampun lagi Maha Penyayang.

${ }^{31}$ Ibn Katsîr, Tafsîr Ibn Katsîr..., vol. 1, h. 154-155.

${ }^{32}$ al-Qaysî, al-Îdhâh...., h. 157. 
b. Q.9/113:29.

Perangilah orang-orang yang tidak beriman kepada Allah dan tidak pula kepada hari kiamat serta tidak mengharamkan apa yang telah diharamkan oleh Allah dan rasul-Nya dan tidak beragama dengan agama yang benar, yaitu orang-orang yang diberikan al-Kitâb hingga mereka mau membayar jiayah dengan patuh dan tunduk.

c. Q.9/113:36.

Sesungguhnya bilangan bulan pada sisi Allah adalah dua belas bulan, dalam ketetapan Allah di waktu Dia menciptakan langit dan bumi, di antaranya empat bulan suci. Itulah (ketetapan) agama yang lurus. Maka janganlah kamu menganiaya diri kamu dalam bulan tersebut, dan perangilah kaum musyrik itu semuanya sebagaimana merekapun memerangi kamu semuanya, dan ketahuilah bahwa Allah beserta orang-orang yang bertakwa.

d. Q.9/113:41.

Berangkatlah kamu ke medan perang, baik dalam keadaan merasa ringan maupun berat, dan berjihadlah kamu dengan harta dan dirimu di jalan Allah. Yang demikian itu adalah lebih baik bagimu jika kamu mengetahui.

e. Q.9/113:73.

Hai Nabi, berjihadlah (melawan) orang-orang kafir dan orangorang munafik itu, dan bersikap keraslah terhadap mereka. Tempat mereka adalah Jahanam, dan itu adalah tempat kembali yang paling buruk.

f. Q.49/106:9.

Jika ada dua golongan dari mereka yang beriman berseteru, hendaklah kamu damaikan antara keduanya. Tapi, jika salah satu di antara keduanya melanggar perjanjian terhadap yang lain, perangilah yang melanggar perjanjian itu sampai mereka kembali kepada perintah Allah. Jika telah kembali, damaikanlah antara keduanya secara adil, dan berlakulah secara adil. Sesungguhnya Allah mencintai orangorang yang berlaku adil. 


\section{Tahap Perkembangan Pemikiran tentang Penganuliran}

\section{Keterangan Awal 'Alî bin Abî Thâlib dan Ibn 'Abbâs.}

Sebagaimana dikutip al-Majlisî dari Tafsir al-Nu'mânî karya Muhammad bin Ibrâhîm bin Ja'far al-Nu'mânî (w. 360 H/ 971 M), ${ }^{33}$ murid al-Kulaynî (w. 329 H), 'Alî diriwayatkan menyatakan bahwa perintah mengatakan yang baik kepada manusia (Q.2/87:83), yang secara kontekstual ditafsirkan ditujukan kepada Yahudi yang mengadakan perjanjian damai dengan Nabi, dibatalkan dengan Q.9/113:29, ${ }^{34}$ âat al-sayf, atau lebih dikenal sebagai âyat al-jiżyah.

Ibn 'Abbâs, sebagaimana dikutip oleh Abû 'Ubayd, berpendapat bahwa sejumlah "ayat damai”, yaitu yang menekankan bahwa misi Rasul bukan untuk menjadi penguasa dan melakukan dominasi politik (Q.88/ 68:22), tidak melakukan pemaksaan (Q.50/34:45), dan anjuran untuk memaafkan (Q.5/112:13/ Q.3/89:159) dan (Q.45/65:14) dianulir oleh Q.9/113:5 dan Q.9/113:29. ${ }^{35}$ Sedangkan, ayat yang berisi perintah menerima ajakan berdamai (Q.8/88:61) dianulir oleh Q.9/113:29. ${ }^{36}$

Dengan demikian, dalam Syî'ah, penisbatan kepada 'Alî adalah berkaitan dengan status penganuliran yang mendahului munculnya istilah ayat pedang pada Abû Ja'far. Dalam Sunnî, status penganuliran tersebut

${ }^{33}$ al-Nu'mânî dikenal juga sebagai Ibn Abî Zaynab. Nisbah al-Nu'mânî menunjukkan asal keluarganya di al-Nu'mânîyah yang, menurut Yâqût al-Hamawî, merupakan sebuah kota kecil antara Wâsith dan Baghdad yang dihuni oleh Shî’ah ekstrem. Menurut al-Najâshî, ia menulis beberapa karya, antara lain: Kitâb al-Ghaybah, Kitâb al-Farâith, dan Kitâb al-Radd 'alâ al'Ismẩ̂lîyah. Menurut Bar-Asher, beberapa imam awal menyebut keberadaan tafsir ini. Menurut Muhsin al-Amîn, penulis A'yân al-Shîah, dengan mengutip pernyataan Ibn Shahrâshûb, alNu'manî memang pernah menulis karya tafsir. Sedangkan, dalam al-Fibrist al-Nadîm maupun al-Thûsî, al-Nu'mânî tidak disebut. Beberapa penafsiran al-Nu'mânî dikutip dalam Bị̂âr alAnwâr al-Majlisî. Menurut al-Nu'mânî, tafsirnya diriwayatkan dari 'Alî. Karya ini merupakan salah satu di antara karya tafsir awal Shî’ah Imâmîyah pra-Buwayh. Lihat Me'ir Mikha'el BarAsher, Scripture and Exegesis in Early Imâmî-Shiism (Leiden: Brill, 1999), 63-64.

${ }^{34}$ Muhammad Bâqir al-Majlisî, Bihbâr al-Anwâr al-Jâmi'ab li Durar Akbbâr al-A 'immah alAthbâr, vol. 97 (Beirût: Mu'assasat al-Wafâ', 1983), h. 30.

${ }^{35} \mathrm{Abu \hat { }}$ 'Ubayd, al-Nâsikh wa al-Mansûkh..., h. 156. Lihat juga Ibn al-Jawzî, Nawâsikh alQur'ân (Beirût: Dâr al-Kutub al-'Ilmîyah, t.th.), h. 145. Ketika menjelaskan naskh firman Allah “fa'fu 'anhum” (Q.5/112:13, Q.3/89:159) dan "wa an ta'fû wa tashfab̂u’' (Q.64/108:14), Ibn alJawzî mengatakan: "Ayat-ayat seperti ini dalam al-Qur'an semuanya dinaskh dengan firman Allah "faqtulû al-mushrikîn h?aytsu wajadtumûhum" (Q.9/113:5).

${ }^{36} \mathrm{Abu \hat { }}$ Ubayd, al-Nâsikh wa al-Mansûkh..., h. 158. 
dinisbatkan kepada Ibn 'Abbâs, seperti tampak pada Abû 'Ubayd dan Qatâdah, dan status penganuliran tersebut sama-sama mendahului kemunculan istilah tersebut dalam tafsir Ibn Abî $\underline{\text { Hâtim. }}$.

\section{Generalisasi al-Dhahhâk dan Qatâdah.}

Berdasarkan pendapat tersebut, pada awal abad ke-2 H, al-Dhahhâk bin Muzâhim (w. 105 H/ 723 M), seorang tâbi'̂̂ penukil tafsir-tafsir Ibn 'Abbâs, menggeneralisasi klaim penganuliran Ibn 'Abbâs berkaitan dengan ayat-ayat tersebut juga berlaku terhadap ayat-ayat lain yang berdasarkan "ijtihad" penulis naskh dan mufassir juga memiliki kandungan yang sama, yaitu pembatalan terhadap ayat-ayat yang berisi perjanjian damai dengan kelompok non-muslim. Dari sini, tampak berkembang "analogi” untuk menarik kesimpulan yang lebih umum: "Setiap ayat dalam kitab Allah ta'âlâ yang berisi perjanjian antara Nabi Muhammad saw. dengan setiap orang dari kalangan orang-orang musyrik, setiap ikatan perjanjian, dan setiap kurun waktu (yang sudah disepakati) dibatalkan oleh (ayat dalam) sûrat Barâ'ah "tangkaplah, tawanlah, dan intailah mereka di tempat pengintaian" 37 Tampaknya, ada ambiguitas karena status luar biasa Q.9/113:5 ini juga dilekatkan pada Q.22/103:39, ayat pertama tentang izin berperang, yang dianggap menganulir ayat-ayat senada, yaitu ayat-ayat perintah untuk tidak menghiraukan orang-orang musyrik, meninggalkan perang, dan memaafkan mereka. ${ }^{38}$ Pada abad yang sama, Qatâdah (w. $117 \mathrm{H}$ ) juga membuat generalisasi berkaitan dengan penganuliran semua ayat yang berisi anjuran "berpaling" (i'râdh; tidak mengganggu) atau hanya menunggu dan menerima keadaan: "Setiap ayat dalam al-Qur'ân yang berisi perintah 'berpaling dari mereka dan tunggulah' dianulir oleh Barâ’ah dan (ayat) perang. ${ }^{39}$ Dalam beberapa literatur tafsir, seperti tafsir karya al-Qurthubî, ${ }^{40}$

${ }^{37}$ al-Dhahhâk, Tafsîr al-Dhahbahk, vol. 2, kompilasi Shukrî Ahmad al-Zâwînî (Beirût: Dâr al-Salâm, 1419 H/ 1999 M), h. 399. Pendapat ini dikutip oleh Ibn Katsîr (Tafsìr Ibn Katsîr..., vol. 2, h. 337).

${ }^{38}$ al-Dhahhâk, Tafsîr al-Dhahhâk..., vol. 2, h. 590.

${ }^{39}$ Ibn al-Jawzî, Nawâsikeh al-Qur'ân..., h. 208.

${ }^{40}$ al-Qurthubî, al-jâmi' li A hlkâm al-Qur'ân, vol. 8 (Beirût: Mu'assasat al-Risâlah, 2006), h. 73. 
Ibrâhîm al-Tha'labî, ${ }^{41}$ Ibn 'Âdil al-Dimasyqî, ${ }^{42}$ dan Muhammad bin A $\underline{h}$ mad al-Syarbînî, ${ }^{43}$ generalisasi tersebut diriwayatkan berasal dari al- $\underline{\text { Hu}}$ usayn bin al-Fadhl al-Bajalî (w. 282 H/ 895 M), otoritas yang sebenarnya tidak lebih awal daripada al-Dhahhâk. Munculnya riwayat dari al-Bajalî tersebut mungkin dimaksudkan sebagai alternatif riwayat tafsir dari al-Dhahhâk yang validitas riwayat-riwayatnya dipersoalkan. ${ }^{44}$ Setelah itu, pada abad ke-3 H, Abû 'Ubayd (w. 224 H/ 838 M) bahkan menarik generalisasi "(Sûrat) Barầah membatalkan perjanjian dan memunculkan jïhâd sebagai kewajiban terhadap kaum muslim". ${ }^{5}$

\section{Pembakuan Naskh dengan Ayat Pedang Sebagai Kaedah: Peran Hibatullâh (w. 410 H/ 1019 M) dan Ibn al-‘Arabî (w. 543 H/ 1148 M).}

Dengan berpatokan pada generalisasi dengan dasar analogi di atas, pada abad ke-5 H, Hibatullâh ibn Salâmah (w. 410 H/ 1019 M) mengembangkan daftar ayat-ayat teranulir dan menyimpulkan bahwa ayat pedang "menganulir 124 ayat Alquran, kemudian bagian akhir ayat ini menganulir bagian akhirnya." "46 Hibatullâh mengemukakan kaedah-kaedah berikut:

a. Kaedah penganuliran ayat-ayat perintah "berpaling" (âyât al-irâdh), bersabar (âyât al-shabr), dan memaafkan (âyât al-'afw wa al-shafh):

Setiap ayat dalam Alquran dari firman Allah ta'âlâ "berpalinglah dari mereka" (فأعرض عنهم), firman-Nya "bersabarlah atas apa yang mereka

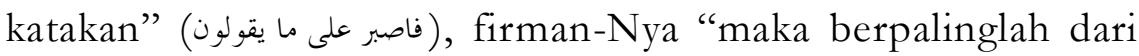

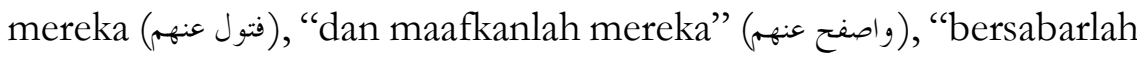
dengan sabar yang baik" (واصبر صبرا جميلا), dan "maafkanlah dengan pemberian maaf yang baik" (اصفح الصفح الجميل)), maka ayat ini dan

\footnotetext{
${ }^{41}$ Ibrâhîm al-Tsa'labî, al-Kashf wa al-Bayân, vol. 5, ed. Abû Muhamamad bin 'Âshûr (Beirût: Dâr Ihyâ’ al-Turâts al-'Arabî, 2002 M/ 1422 H), h. 12 .

${ }^{42}$ Ibn 'Âdil al-Dimashqî, al-Lubâb fî̀ Ulûm al-Kitâb, vol. 10, ed. Shaykh 'Âdil Aḥmad 'Abd al-Mawjûd (Beirût: Dâr al-Kutub al-'Ilmîyah, 1998 M/ 1419 H), h. 19.

${ }^{43}$ Muhammad bin Ahmad al-Sharbînî, Tafsîr al-Sirâj al-Munîr, vol. 1 (Beirût: Dâr alKutub al-'Ilmîyah, t.th.), h. 466.

${ }^{44}$ al-Suyûthî, al-Itqân fì 'Ulùm al-Qur ân, vol. 2 (Beirût: Dâr al-Fikr, t.th.), h. 189.

${ }^{45}$ Abû 'Ubayd, Kitâb al-Nâsikh wa al-Mansûk.h..., h. 160.

${ }^{46}$ Hibatullâh, al-Nâsikh..., h. 184.
} 
serupa dengannya dianulir dengan âyat al-sayf. ${ }^{47}$

Setiap ayat dalam Alquran yang memuat berita "orang-orang yang diberikan kitab” (الذين أوتوا الكتاب) dan perintah untuk memaafkan mereka dianulir oleh firman Allah ta'âlâ, "Bunuhlah orang-orang yang tidak beriman dengan Allah dan tidak (juga) dengan hari kiamat...(sampai akhir ayat)" 48

b. Kaedah penganuliran ayat-ayat perjanjian damai (âyât al-muwâda'ah/ al-mu'âhadah/al-muhâdanab):

Setiap ayat dalam Alquran yang memuat perjanjian damai dianulir oleh ayat dalam sûrat Barâ'ah "(Inilah pernyataan) pemutusan hubungan dari Allah dan Rasul-Nya" (براءة من الله ورسوله) sampai awal ayat lima dari surah tersebut. ${ }^{49}$

c. Kaedah penganuliran ayat-ayat yang menyatakan bahwa perbuatanperbuatan setiap hamba menjadi tanggung-jawab masing-masing di akherat nanti:

Setiap ayat dalam Alquran yang memuat "Dan bagi kami perbuatanperbuatan kami, dan bagi kalian perbuatan-perbuatan kalian" dianulir oleh âyat al-sayf. ${ }^{50}$

Setelah Hibatullâh, Ibn al-'Arabî (w. 543 H), meski mengkritisi penganuliran jumlah ayat yang dikemukakan oleh para mufassir sebelumnya, menguatkan kembali prinsip al-Dhahhâk bahwa ketentuan baru dalam ayat tersebut membatalkan setiap ketentuan sebelumnya, dan bahwa perintah perang membatalkan setiap perintah memaafkan dan perintah tidak mengganggu komunitas non-muslim. ${ }^{51}$ Bahkan, perintah memerangi $A b l$

${ }^{47}$ Hibatullâh, al-Nâsikh, ed. Zuhayr al-Shâwîs dan Muhammad Kan'ân (Beirût: al-Maktab al-Islâmî, 1404H), h. 209. Edisi terbitan Maktabat al-Mutanabbî yang penulis rujuk sebelumnya tidak memuat kaedah ini.

${ }^{48}$ Hibatullâh, al-Nâsikh (edisi al-Maktab al-Islâmî), h. 210.

${ }^{49}$ Hibatullâh, al-Nâsikh..., (edisi al-Maktab al-Islâmî), h. 210-211.

${ }^{50}$ Hibatullâh, al-Nâsikh..., (edisi al-Maktab al-Islâmî), h. 211.

${ }^{51}$ Abû Bakr ibn al-'Arabî, al-Nâsikh wa al-Mansûkh fî al-Qur'ân al-Karîm, ed. Shaykh Zakarîyâ 'Umayrât (Beirût: Dâr al-Kutub al-'Ilmîyah, 2006), h. 141. Menurut al-Shaykh Zakariyyâ 'Umayrât, di antara patokan-patokan (qawâ'id) yang dipegang oleh Ibn al-'Arabî dalam menentukan naskh adalah "setiap ancaman dalam al-Qur'an di-naskh dengan ayat-ayat perang" (kull tablîd fì al-Qur'ân mansûkkh bi âyât al-qitẩ) (al-Shaykh Zakariyyâ 'Umayrât, "al-Muqaddimah", h. 4). Meskipun mengakui prinsip ini, berkembangannya secara dramatis jumlah ayat-ayat 
al-Kitâb adalah ketetapan berdasarkan kaedah ushûl al-fiqh yang berlandaskan ketentuan universal (al-tabqî́q al-ushîhî al-jârî̀ 'alâ al-qânûn al-kullì). Dipicu oleh berbagai perang yang selalu mengiringi perkembangan Islam, para penulis mengidealisasikan adanya suatu penopang formulasi dari kitab suci (scriptural prop of a formulation) melalui naskh dalam 'ulum al-Qur'ân yang memuat sikap final mereka terhadap hubungan mereka dengan non-muslim di semua situasi apa pun. ${ }^{52}$ Formulasi berikut yang sebenarnya substansinya berasal dari Hibatullâh yang dikutip oleh al-Suyûthî (w. $911 \mathrm{H}$ ) dalam alItqân fî 'Ulùm al-Qư'ân sebagai formulasi Ibn al-'Arabî, menunjukkan bahwa yang disebut terakhir ini berpengaruh terhadap penulis-penulis sesudahnya:

Setiap ayat Alquran yang berisi pemberian maaf terhadap orangorang kâfir, perintah berpaling, dan tidak mengganggu mereka dibatalkan dengan ayat pedang, yaitu firman Allah "Apabila bulan-bulan suci telah berakhir, bunuhlah orang-orang musyrik", dan seterusnya, yang membatalkan seratus dua puluh empat ayat, kemudian bagian akhir ayat tersebut membatalkan bagian awalnya. ${ }^{53}$

Dengan pembakuan tersebut, pendapat bahwa ayat pedang menganulir ayat-ayat sampai diterima di kalangan tokoh Islam, meskipun terjadi perkembangan dramatis, dari semula hanya sedikit hingga ratusan ayat damai.

Ayat-ayat damai yang diklaim teranulir bisa diklasifikasi kepada tiga macam sebagai berikut: Pertama, ayat-ayat teranulir yang memuat nilai (qimah) dan prinsip yang menentukan arah penyebaran Islam, yaitu: (a) ayatayat tentang kebebasan beragama; (b) ayat-ayat pemberian peringatan (âyât al-indhâr), yaitu ayat-ayat tentang prinsip bahwa misi Nabi hanya sebagai

mansûkh yang tampak memuncak pada karya Hibatullâh menggelisahkan para mufassir semisal Ibn al-'Arabî, Ibn al-Jawzî, dan al-Suyûthî. Kesadaran akan hal ini tampak berkorelasi dengan berkembangnya ilmu munâsabât al-âyât, seperti tampak pada karya Ibn al-'Arabî, Sirâj al-Murî́în, dan karya al-Suyûthî, Tanâsuq al-Durar (Asrâr Tartîb al-Qur'ân), ringkasan dari karyanya yang lebih lengkap (al-Suyûthî, al-Itqân fì Ulùm al-Qur'ân ..., vol. 2, h. 108). Sedangkan, Ibn al-Jawzî memiliki kesadaran akan transmisi tafsir (naqlal-tafsîr) secara tidak kritis.

${ }^{52}$ Wansbrough, Quranic Studies: Sources and Methods of Scriptural Interpretation (Oxford: Oxford University Press, 1977), h. 184.

${ }^{53}$ Jalâl al-Dîn al-Suyûthî, al-Itqân fì 'Ulûm al-Qur'ân, vol. 2 (Beirût: Dâr al-Fikr, t.th.), h. 24. Perujukan al-Suyûthî kepada Ibn al-'Arabî dalam naskeh ayat pedang ini juga dikemukakannya dalam al-Tablbîrfí Tlm al-Tafsîr (Cairo: Dâr al-Manâr, 1986), h. 252; Mu'tarak al-Aqrân fí I'jâz alQur'ân, vol. 1 (Beirût: Dâr al-Fikr al-'Arabî, t.th.), h. 121. 
penyampai risalah agama, bukan pengemban misi politik sebagai pemaksa/

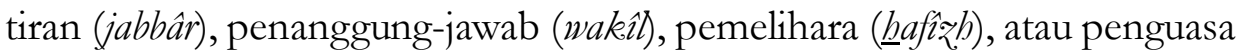
(musaythir); (c) ayat-ayat tentang prinsip penyebaran Islam tanpa kekerasan.

Kedua, ayat-ayat teranulir yang memuat perintah sebagai penerapan dari nilai dan prinsip tersebut dalam berinteraksi dengan komunitas nonmuslim, yaitu: (a) ayat-ayat kesabaran (âyât al-shabr); (b) ayat-ayat pemberian maaf dan tidak menuntut balas (âyât al-'afw wa al-shafb); (c) ayat-ayat "berpaling" (âyât al-irâdb) untuk tidak membalas perlakuan buruk orangorang yang menolak Islam; (d) ayat-ayat perintah menyerahkan urusan kepada Allah; (e) ayat-ayat perintah berlaku baik; (f) ayat-ayat perintah mengindahkan perjanjian damai (âyât al-muwâda'ab/al-mu'âhadah/ almubâdanab).

Ketiga, ayat-ayat teranulir yang pada dasarnya memuat larangan, yaitu ketika terjadi ketegangan (tension) hubungan antarpemeluk agama yang mengarah kepada perang yang sebenarnya tidak diinginkan, sehingga perlu ditentukan regulasi, yaitu: (a) ayat-ayat tentang perintah menjaga hubungan baik dengan orang-orang kafir, semisal dengan menghindari terjadinya berperang; (b) ayat-ayat regulasi jika perang tak terhindarkan yang memuat: prinsip tentang hukuman setimpal (mu'âwadhah; reciprocity), ketentuan perang defensif, dan larangan berperang di tempat dan bulan suci, serta larangan melanggar syiar-syiar Allah.

\section{Faktor-faktor Ideologis yang Mempengaruhi Penafsiran}

\section{Faktor Teologis}

Sebagian ulama, seperti al-Syâfi'î dan Ibn Hazm al-Zhâhirî, berpendapat bahwa alasan yang membolehkan perang adalah kekufuran (kufr). Kedua tokoh ini tidak mengecualikan orang-orang yang tidak berbahaya, seperti anak-anak, wanita, orang tua lanjut usia, dan pemuka agama yang tidak berbahaya, untuk dibunuh dengan alasan, antara lain, bahwa yang dimaksud dengan "fitnah" (Q.2/87:193) adalah syirk, ${ }^{54}$ terlepas dari apakah mereka berbahaya atau tidak. Ibn al-'Arabî berpendapat bahwa tidak ada perbedaan antara Ahl al-Kitâb dan orang-orang musyrik dalam hal bahwa

\footnotetext{
${ }^{54}$ Lihat al-Syâfî̀, al-Umm, vol. 7 (Cairo: Kitâb al-Sha’b, 1967), h. 181.
} 
mereka semuanya orang-orang kafir, meski bisa dibedakan bahwa setiap kitâbî adalah musyrik, tapi tidak sebaliknya. Bahkan, Ibn al-'Arabî menganggap Mu'tazilah dan Qadarîyah termasuk orang-orang kafir, karena mereka menyamakan hamba dan Tuhan dalam terwujudnya perbuatan (khalq af'al al-ibâd)..$^{55}$ Itu artinya bahwa, menurutnya, para penganut sekte teologi dalam Islam ini juga harus diperangi.

\section{Faktor Fiqh}

Teori naskh sering diterapkan untuk kepentingan fanatisme aliran. Seabad setelah al-Syâfi'î, penganuliran (naskh) sebagai metode yang digunakan hanya untuk pembelaan fanatisme aliran fiqh sangat tampak dari pernyataan 'Abdullâh al-Karkhî (w. 340 H/ 951 M), seorang tokoh aliran

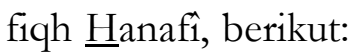

Pada prinsipnya, setiap ayat yang bertentangan dengan pendapat para tokoh aliran kami harus dibawa ke isu penganuliran (naskb) atau pertimbangan pendapat terkuat (tarjîh $)$. Yang lebih tepat adalah dita'wil untuk melakukan kompromi. ${ }^{56}$

Di samping itu, penganuliran ayat-ayat damai didorong oleh merebaknya literalisme ushûl al-fiqh, seperti yang dianut oleh Ibn al-'Arabî, yang didasarkan atas pemaknaan harfiah terhadap teks, sebagaimana dijelaskannya, "keharusan melabuhkan ungkapan-ungkapan pada maknamakna lahiriahnya yang layak" (wujû̉ tanzîl al-alfẫ̧ 'alâ ma' ânîhâ al-z̧hâhirah fîhâ al-lầiqab). ${ }^{57}$ Literalisme begitu kuat dalam pemikiran hukum Islam, seperti tampak dari pernyataan Ibn $\underline{H}$ azm dalam al-Muhallâ bahwa barangsiapa yang mengatakan bahwa ada dimensi batin dalam ajaran Islam selain yang lahiri adalah orang kafir yang harus dibunuh. ${ }^{58}$

${ }^{55}$ Ibn al-'Arabî, al-Nâsikh wa al-Mansûkh..., h. 143.

${ }^{56}$ Sebagaimana dikutip oleh Shaykh A $\underline{h}$ mad bin al-Shaykh Muhammad al-Zarqâ, Shar $\underline{b}$ al-Qawâ'id al-Fiqhîyah, ed. 'Abd al-Sattâr Abû Ghuddah (Damaskus: Dâr al-Qalam, 1996), h. 39; Muhammad Husayn al-Dzahabî, al-Tafsîr wa al-Mufassirûn, vol. 2 (Beirût: Dâr al-Fikr, 1976/ 1396), h. 434. Di antara karya al-Karkhî adalah Mukhtas?ar fî Furû' al-Fiqh al- $\underline{H}$ anafî.

${ }^{57}$ Ibn al-'Arabî, al-Nâsikh wa al-Mansûkh..., h. 139.

${ }^{58} \mathrm{Ibn} \underline{\mathrm{H}}$ azm, al-Muballâ bi al-Âtsâr, suntingan 'Abd al-Ghaffâr Sulaymân al-Bindârî (Beirût: Dâr al-Fikr, t.th.), juz 5, h. 376. 


\section{Faktor Ajaran Tasawuf}

Sebagaimana dicatat oleh S. Abdullah Schleifer, tasawuf berperan dalam berbagai moment pergolakan Islam. Kharisma 'Alî dikembangkan sebagai simbol penopang kekuatan politik 'Abbâsîyah yang berakselerasi dengan perkembangan tasawuf. Ide tentang "fatâ' (pemuda, kesatria) 'Alî dikembangkan menjadi konsep "futûwah" (kesatriaan yang saleh) untuk menggelorakan jihâd. ${ }^{59}$

Tidak kurang pentingnya adalah peran tasawuf sebagai justifikasi doktrinal untuk menggelorakan jihâd selama perang Salib. Setting historispolitis-keagamaan ini yang mengendalikan kesadaran seorang Ibn al-'Arabî dalam alasan sufistiknya yang mendasari penganuliran ayat-ayat damai. Menurutnya, teranulirnya "ayat-ayat pemberian peringatan" (âyât al-indhâr) dengan "ayat perang" (âyat al-qitẩ) atau "ayat pedang" (âyat al-sayf) adalah karena memang Nabi Muhammad saw. diciptakan oleh Tuhan dengan sifatsifat-Nya juga "mendua", seperti Tuhan maha Pengasih sekaligus Maha Penghukum. ${ }^{60}$ Wajar kemudian, menurutnya, Nabi juga memiliki karakter "mendua": pemberi peringatan sekaligus pembunuh, ${ }^{61}$ pemberi peringatan sekaligus pembunuh dan penguasa terhadap semua umat, kecuali penganut agama Islam, ${ }^{62} \mathrm{Nabi}$ rahmat sekaligus Nabi perang, pemaaf sekaligus penghukum, murah senyum sekaligus pembunuh, pemberi peringatan sekaligus pemberi perhitungan, atau pemaaf sekaligus pembalas dendam. ${ }^{63}$

Justifikasi Ibn al-'Arabî tersebut merujuk ke konsep tasawuf tentang meniru sifat-sifat Tuhan yang dikatakan bersumber dari sabda Nabi, "Berakhlaklah dengan akhlak Allah" (takhallaqû bi akhlâq Allâh). ${ }^{64}$ Bahkan,

${ }^{59}$ S. Abdullah Schleifer, "Jihâd and Traditional Islamic Consciousness", dalam The Islamic Quarterly, vol. 27, no. 4 (1983), h. 192-193.

${ }^{60} \mathrm{Ibn}$ al-'Arabî, al-Nâsikh wa al-Mansûkh..., h. 153-154.

${ }^{61}$ Ibn al-'Arabî, al-Nâsikh wa al-Mansûkk..., h. 199.

${ }^{62} \mathrm{Ibn}$ al-'Arabî, al-Nâsikh wa al-Mansûkh..., h. 225.

${ }^{63} \mathrm{Ibn}$ al-'Arabî, al-Nâsikh wa al-Mansûkh..., h. 188.

${ }^{64}$ Sepanjang pelacakan penulis, pernyataan ini tidak ditemukan dalam koleksi-koleksi hadîts standar, baik kitab-kitab hadîts sembilan, maupun kitab-kitab hadîts level di bawahnya. Menurut al-Albânî, pernyataan ini tidak ada dasarnya sama sekali untuk dikategorikan sebagai hadîts (lâ ashla labu). Muhammad Nâshir al-Dîn al-Albânî, al-Silsilah al-Dha'îfah, vol. 6 (Riyâdh: Maktabat al-Ma'ârif, t.th.), h. 323; idem, Shark al-'Aqîdah al-T?ah?âwîyah li Ibn 'Abd al-'Tzz alHanafí (Beirût: al-Maktab al-Islâmî, 1414 H), h. 113. 
dalam al-Siyar al-Kabîr karya Muhammad al-Shaybânî, karakter Nabi digambarkan secara dramatis dengan penjelasan bahwa karakter tersebut sudah disebutkan dalam Tawrat sebagai "nabi perang, kedua matanya memerah, karena kuatnya keinginan berperang". ${ }^{65}$ Menurut Murtadhâ alZubaydî dalam kamus Tâj al-'Arûs dan Ibn Manzhûr dalam Lisân al-'Arab, ungkapan "nabî al-malhamah" sebenarnya mengandung dua kemungkinan makna. Pertama, "nabi perang" (nabî al-qitâl) sebagaimana digambarkan oleh para penulis tersebut. Kedua, "nabi kebaikan dan penata umat" dari kata labama al-amr (menguasai suatu persoalan). Makna ini diriwayatkan oleh al-Zuhrî dari Shamir. ${ }^{66}$

\section{Pengaruh Penganuliran Ayat-ayat Damai dengan Ayat Pedang dalam Formasi Fiqh Jihâd}

\section{Ayat Pedang dan Legislasi Perang}

Ayat pedang tidak hanya dijadikan rujukan oleh para mufassir, melainkan juga oleh para ahli figh dalam menjelaskan proses legislasi perang dari semula berupa pembolehan perang defensif hingga menjadi keharusan perang ofensif dan tidak bersyarat. Yang menjadi tolak penganuliran ayatayat damai dengan ayat pedang dalam hal ini adalah penjelasan Ibn 'Abbâs bahwa ayat-ayat damai hanya berlaku ketika kaum muslim merupakan minoritas di Makkah, dan ayat-ayat tersebut dianggap teranulir dengan ayat pedang dalam fase Madinah ketika mereka sudah menjadi komunitas mayoritas dan memiliki kekuatan politik. "Logika kekuatan" ini menjadi dasar penganuliran yang dianut oleh para mufassir yang kemudian berpengaruh kuat dalam penjelasan kalangan ahli fiqh dan ushûl al-fiqh.

\section{Jihâd-Perang (al-Jihâd al-Qitâlı̂) sebagai Kewajiban Permanen}

Dengan teori naskh dan kronologi legislasi perintah perang di atas, para ahli figh sepakat bahwa fase akhir legislasi tersebut adalah perintah

${ }^{65}$ Lihat al-Sarakhsî, Sharh al-Siyar al-Kabîr, vol. 1, 7 (pembahasan fadhîlat al-ribâth), dalam www.al-mostafa.com. Karya ini adalah penjelasan al-Siyar al-Kabîr karya Muhammad bin alHasan al-Shaybânî.

${ }^{66}$ Murtadhâ al-Zubaydî, Tâj al-'Arûs, vol. 1 (t.tp: Dâr al-Hidâyah, t.th.), h. 7890 (pasal hurup lâm); Ibn Manzhûr, Lisân al-'Arab, vol. 12 (Beirût: Dâr Shâdir, t.th.), h. 535. 
(wajib) perang, meski dalam kesimpulan tampak berbeda:

a. Al-Syâfi'î berkesimpulan bahwa fase akhir legislasi merupakan kewajiban perang yang tidak bisa ditawar. Dari penganuliran ayatayat perang defensif dengan Q.2/87:193, tampak bahwa kewajiban perang yang dimaksud adalah kewajiban perang ofensif, apalagi ia berpandangan bahwa alasan yang membolehkan perang adalah kekufuran (kufr).

b. Abû 'Ubayd berkesimpulan bahwa apa yang disebutnya penguatan perintah perang adalah diizinkannya memerangi orang-orang musyrik setelah bulan-bulan suci berakhir dan pembatalan perjanjian damai dengan mereka. Dari penganuliran ayat-ayat perang defensif dengan Q.9/113:5 dan Q.9/113:29, jelas bahwa penguatan perintah perang tersebut berkaitan dengan perang ofensif.

c. Al-Haytamî, al-Nafrâwî, al-Zayla'î, al-Bâbartî, dan Ibn 'Âbidîn secara lebih tegas berkesimpulan bahwa fase akhir legislasi perang adalah perintah (kewajiban) berperang mutlak, yaitu perang defensif maupun ofensif, pada bulan suci atau bukan.

d. Ibn al-Jawzî berpendapat bahwa fase akhir legislasi perang adalah diwajibankannya perang secara kolektif (fardu kifâyab).

Atas dasar kronologi dan teori penganuliran, mereka menyimpulkan bahwa perang adalah kewajiban abadi yang berlaku hingga hari kiamat yang harus dilaksanakan minimal sekali setahun. ${ }^{67}$

Imam Samudra, ketika ditanyakan kepadanya, "tampaknya Anda sangat terpengaruh dengan konflik di Afganistan, dan juga mungkin di Palestina, apakah Anda akan berhenti kalau konflik itu selesai?", menjawab dengan berargumentasi begini:

Saya menjawab ini dengan mengutip firman Allah swt., "Dan perangilah mereka sampai tak ada fitnah." ${ }^{68}$ Hanya ada satu jalan, yaitu jïhâd. Ada tafsir dari Ibn Katsîr soal fitnah itu. Pertama, syirk. Kedua, tidak menegakkan hukum

\footnotetext{
${ }^{67}$ Ahmad bin Ghanîm bin Sâlim al-Nafrâwî, al-Fawâkih al-Dawânî..., vol. 2, h. 879. Lihat juga al-Ramlî, Nihâyat al-Mubtâj, vol. 8 (Beirut: Dâr al-Fikr, 1984), h. 46.

${ }^{68}$ Yang dimaksud oleh Imam Samudra adalah "Dan perangilah mereka sampai tak ada fitnah (penindasan) dan agama bagi Allah. Jika mereka berhenti (dari menindasmu), tidak ada lagi permusuhan, kecuali terhadap orang-orang aniaya" (Q.2/87:193).
} 
Allah. ${ }^{69}$ Jadi, untuk mengeliminasi fitnah itu, hanya ada satu cara, dengan jih âd. Bukan lewat pemilihan umum, bukan dengan demokrasi. Itu konsep Barat dan yang sekarang menjadi dîn atau agama baru. Lalu banyak umat Islam

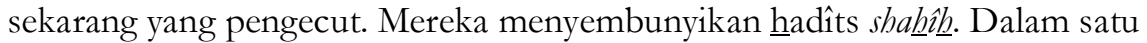
hadîts yang diriwayatkan Bukhârî-Muslim disebutkan, "Aku diutus oleh Allah menjelang hari kiamat dengan membawa pedang." ${ }^{70}$ Itu hadîts shabih $\underline{\text { h. }}{ }^{71}$

${ }^{69}$ Ibn Katsîr juga mengemukakan penafsiran yang menekankan konteks hukum timbalbalik (reciprocity) dengan mengemukakan riwayat lain. Penafsiran ini didasarkan pendapat Ibn 'Abbâs, Abû al-'Âliyah, Mujâhid, al-్asan al-Bashrî, Qatâdah, al-Rabî', Muqâtil, al-Suddî, dan Zayd bin Aslam. Sebenarnya, Q.2/87:193, sebagaimana dikutip, berada dalam kelompok ayatayat lain (ayat 190-193), sebagaimana dikelompokkan oleh Ibn Katsîr, yang harus dipahami dalam korelasi (munâsbah) ayat-ayat tersebut. Ibn Katsîr mencatat bahwa kebolehan berperang didasarkan perlakuan yang sama terhadap umat Islam, karena mereka diperangi (asas timbalbalik, qishâsh, mu'âwadhah, reciprocity), seperti dalam Q.2/87:191. Oleh karena itu, fitnah dipahami dalam konteks seperti pembunuhan, penindasan, atau pengusiran yang dilakukan oleh kaum mushrik Arab kepada umat Islam ketimbang karena shirk mereka. Lihat Ibn Katsîr, Tafsîr Ibn Katsîr, vol. 1 (Beirût: Dâr al-Fikr, 1986), h. 227-229.

${ }^{70}$ Hadits yang dimaksud oleh Imam Samudera tersebut tercantum dalam Musnad Aḥmad

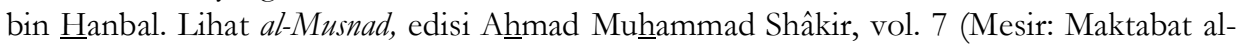

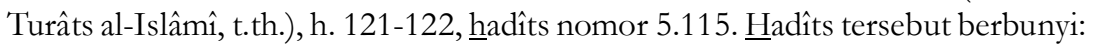

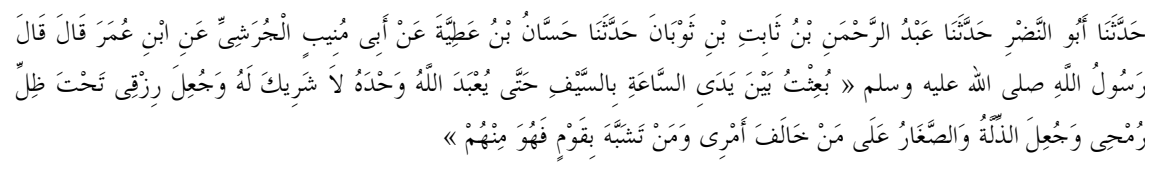

Tidak seperti klaim Imam Samudera, kitab hadîts koleksi al-Bukhârî dan Muslim tidak

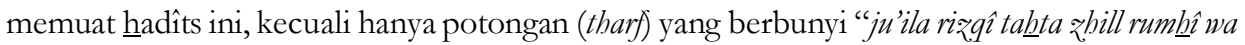
ju'ila al-dhillah wa al-shaghâr 'alâ man khâlafa” yang terdapat dalam Shahîh al-Bukhârîsecara mu'allaq karena al-Bukhârî menyebut sanad secara langsung dari 'Abdullâh bin 'Umar. Lihat al-Bukhârî, Shahîh al-Bukhârî bi Syarh al-Kirmânî, vol. 12 (Beirût: Dâr al-Fikr, t.th.), h. 172. Menurut keterangan

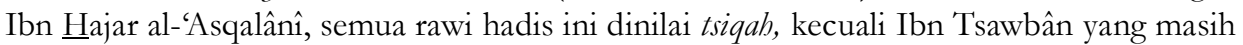
diperdebatkan, namun pada umumnya kritikus rijâlmenilainya juga tsiqah. Lihat Ibn Hajar al'Asqalânî, Tahdžîb al-Tahdž̨̂́b (Beirût: Dâr al-Fikr, 1984), vol. 2, h. 219-220, vol. 6, h. 136-137, vol. 12, h. 18-19, 271. Atas dasar ini, Aḥmad Muhammad Syâkir berkesimpulan bahwa sanad

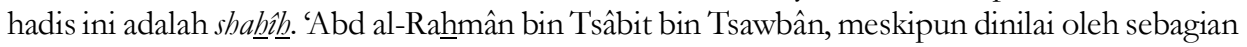

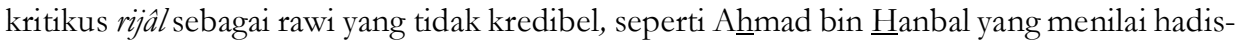
hadis yang diriwayatkannya munkar, dan Yahyâ bin Ma'în yang menilainya dha'îf, sebagian kritikus lain tetap memandang sebagai rawi yang kredibel, seperti 'Alî ibn al-Madînî, Abû

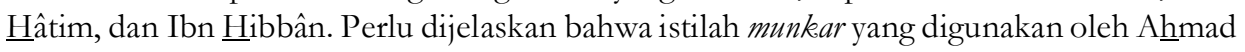

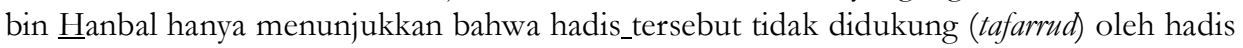

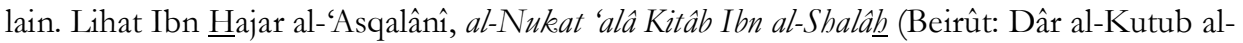
'Ilmîyah, 1994), h. 274. Hadis ini juga tercantum dalam al-Fath al-Kabîr, vol. 3, h. 8 yang berasal

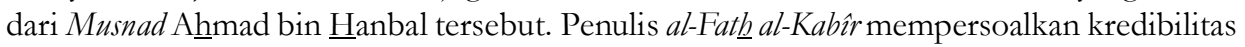
Ibn Tsawbân yang masih kontroversial. Lihat catatan A $\underline{\text { mad }}$ auhammad Syâkir dalam Musnad, 
Dari kutipan di atas, jelas sekali bahwa agama, dalam hal ini teksteks ayat al-Qur'an yang “ditafsirkan”, menjadi salah satu alasan sebuah tragedi kemanusiaan, yaitu pemboman yang menyebabkan tewasnya banyak orang yang tidak berdosa, dengan dalih menghilangkan "fitnah" (syirk) dengan jihâd sebagai kekerasan. Ibn Katsîr (w. 774 H) sebagai otoritas yang dikutip oleh Imam Samudera adalah nama mufassir yang cukup terkenal. Pengutipan sumber pendapat oleh Imam Samudra dari tafsir tersebut memang benar. Ibn Katsîr memang mengemukakan riwayat tersebut, meski ia juga memberikan penekanan adanya hukum qis?âs? (timbal-balik, reciprocity) dalam al-Qur'an. ${ }^{72}$ Bahkan, Ibn Katsîr meriwayatkan terjadinya penganuliran ayat-ayat damai lain dengan ayat pedang tersebut. ${ }^{73} \mathrm{Ibn}$ Katsîr bukanlah satu-satunya mufassir yang menyatakan demikian. Dalam Tafsir al-Jalâlayn, misalnya, dinyatakan bahwa ayat tersebut memuat hanya dua alternatif bagi non-muslim, yaitu konversi ke Islam atau berperang. ${ }^{74}$

\section{Jihâd-Perang (al-Jihâd al-Qitâlî) Sebagai Media Penyebaran Islam}

Dalam persoalan pelaksanaan jihhâd setiap tahun, terdapat perbedaan pendapat di kalangan fuqahâ'. Al-Râfi'î (w. $623 \mathrm{H}$ ) dalam al-'Až̂́ mengemukakan alasan al-Syâfi'î yang mendasarkan ketentuan tersebut pada praktik perang yang dipimpin Nabi (ghazwah) dan pemungutan jizyah dilaksanakan setiap tahun. ${ }^{75}$ Dalam menyikapi pendapat ini, al-Râfi'î meng-

vol. 5, h. 96, vol. 7, h. 121. Di kalangan mubadditsûn, ada salah satu dari dua kaedah yang bisa digunakan untuk menyikapi kontroversi penilaian tersebut, yaitu "al-jar $\underline{\underline{b}}$ muqaddam 'ala al-ta'dîl" dan "al-ta'dîl muqaddam 'alâ al-jarlb". Kaedah pertama tampak lebih hati-hati, apalagi hadis tersebut tidak ditopang oleh hadis lain (syâhid), kecuali hadis yang mursal. Dengan demikian, hadis tersebut dari segi sanad adalah dha'îf.

${ }^{71}$ Lihat http://www.tempointeraktif.com/hg/narasi/2004/09/10/nrs,2004091008,id.html (14 September 2004).

${ }^{72}$ Ibn Katsîr, Tafsîr al-Qur'ân al-'Az̧̧îm..., vol. 2, h. 336-337.

${ }^{73} \mathrm{Ibn}$ Katsîr, Tafsîr al-Qur'ân al-'Az̧̧îm..., vol. 2, h. 337.

${ }^{74}$ Disebutkan "kepunglah mereka di benteng-benteng dan tempat-tempat perlindungan sehingga mereka terpaksa untuk berperang atau masuk Islam”. Lihat Jalâl al-Dîn al-Suyûthî dan Jalâl al-Dîn al-Mahallî, Tafsîr al-Qur'ân al-'Az̧hîm (Tafsîr al-Jalâlayn), vol. 1 (Semarang: Toha Putra, t.th.), h. 156-157; Ahmad al-Shâwî al-Mâlikî, Hâashiyat al-'Allâmah al-Shâwî̀ 'alâ Tafsîr alJalâlayn, vol. 2 (Beirût: Dâr al-Fikr, 1993), h. 137.

${ }^{75}$ al-Râfi'î mencatat bahwa perang-perang dilakukan oleh Nabi setiap tahun terbukti dari rangkaian perang-perang berikut: $\operatorname{Badr}(2 \mathrm{H})$, Uhud $(3 \mathrm{H})$, Dhât al-Riqầ' $(4 \mathrm{H})$, Khandaq (5 
anggap pandangan fuqahâ' tersebut tidak bersifat mutlak, karena hal ini hanya faktor kebiasaan dan ia memilih ketentuan para tokoh ushûl al-fiqh (masâlik al-ushûlîyîn) berikut:

Jihâd adalah dakwah kekerasan (da'wah qahrîyab), maka wajib dilaksanakan sesuai kemampuan, sehingga tidak tersisa lagi, kecuali hanya muslim atau orang yang berdamai (musâlim), tidak mesti hanya sekali dalam setahun, jika mungkin lebih, yang penting kewajiban tersebut tidak terabaikan. ${ }^{76}$

Memang, tidak semua fuqahâ ${ }^{6}$ menerima ketentuan ini. $^{77}$ Namun, penolakan terjadi hanya terkait dengan pernyataan tentang anjuran berjïhâd lebih sekali dalam setahun. Sedangkan, pernyataan bahwa jïhâd adalah dakwah kekerasan tidak diketahui adanya penolakan. Ini menjadi bukti pandangan penting ushûlîyûn tentang jïhâd, meski pun, sepengetahuan penulis, tidak atau belum ditemukan pembakuan pada level ushôl al-fiqh seperti ini dalam literatur-literatur ushûl al-fiqh non-Syâfi'î.

Sebagaimana al-Nafrâwî dari Mâlikî, Syihâb al-Dîn al-Qarâfî (w. 684

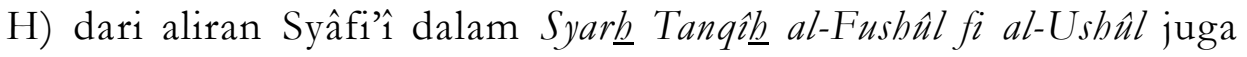
menganggap jïhâd sebagai metode penyebaran Islam. Ia menganggap bahwa ayat-ayat perjanjian damai telah dianulir oleh ayat pedang. ${ }^{78}$

Argumen mayoritas adalah bahwa fundamen-fundamen (keyakinankeyakinan) agama adalah penting lagi agung. Oleh karena itu, Allah ta'âlâ membuat ketentuan tentang kebolehan memaksa dalam soal fundamenfundamen tersebut, bukan soal yang lain, sehingga dilakukan pemaksaan untuk masuk Islam dengan pedang, perang, pembunuhan, pengambilan harta dan keturunan. Itu adalah pemaksaan teragung. ${ }^{79}$

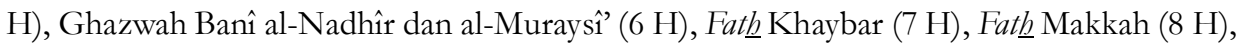

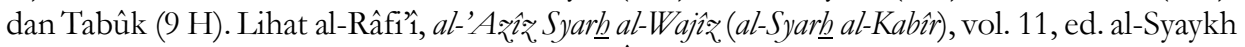
'Alî Muhammad Mu'awwad? dan al-Syaykh 'Âdil Aḥmad 'Abd al-Mawjûd (Beirût: Dâr alKutub al-'Ilmîyah, 1997 M/ 1417 H), h. 346-351. Lihat juga Zakarîyâ al-Anshârî, Asnâ alMathâlib, vol. 4, ed. Muhammad Tâmir (Beirût: Dâr al-Kutub al-'Ilmîyah, 2000), h. 175-176.

${ }^{76}$ al-Râfîî, al-'Azîz Syarb al-Wajî̀ (al-Syarb al-Kabîr), vol. 11, h. 351. Lihat juga dalam alNawawî, Rawdhat al-Thâlibîn, vol. 10 (Beirût: al-Maktab al-Islâmî, 1405 H), h. 209.

${ }^{77}$ Lihat, misalnya, Ibn Hajar al-Haytamî, Tubfat al-Mubtâj (margin), dalam 'Abd al-

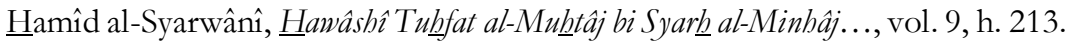

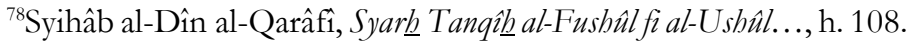

${ }^{79}$ al-Qarâfî, Syark Tanqî̂...., h. 108. 
Di samping itu, al-Qarâfî juga mengatakan bahwa di antara perang yang dimaksudkan untuk mengagungkan Allah ta'âlâ adalah membunuh orang-orang kafir dengan tujuan menghapus kufr dari hati mereka dan merusak salib. ${ }^{80}$ Di antara perang dengan tujuan memusnahkan, menurutnya, adalah perang melawan orang-orang zalim untuk menolak kezaliman mereka, memotong asal kerusakan mereka, menghancurkan rumah-rumah mereka, menebang pohon-pohon mereka, dan membunuh binatangbinatang mereka jika menjadi penghalang perang terhadap mereka, serta menghancurkan sarana-sarana maksiat, seperti berhala dan alat-alat permainan $\left(\right.$ malâhî). ${ }^{81}$

Persoalan teologis yang dihadapi oleh para ushûliyyun yang membenarkan jihâd sebagai metode penyebaran Islam adalah sah kah keimanan seseorang yang dipaksa masuk Islam? Al-Bazdawî dalam karya ushûl alfiqhnya berargumen bahwa pengakuan dengan lisan yang berkaitan dengan pembenaran dalam hati adalah rukun dalam menentukan keberimanan seseorang. Pengakuan lisan tersebut pada dasarnya hanyalah indikasi pembenaran hati, tapi kemudian menjadi rukun sebagaimana berlaku dalam ketentuan-ketentuan hukum di dunia (transaksi) dan di akherat (keyakinan). Atas dasar ini, jika seorang kafir dipaksa untuk beriman, kemudian menyatakan beriman, keimanannya sah karena salah satu rukun tersebut ada, yaitu pengakuan lisan. Hal ini berbeda dengan pemaksaan seorang muslim untuk keluar dari agamanya. Ia tetap dianggap beriman. ${ }^{82}$ Logika yang mendasari argumen dalam dua kasus ini tampak tidak konsisten, karena sebagaimana pada kasus murtad, seharusnya keberimanan yang dipaksa adalah juga tidak sah, karena keyakinan adalah persoalan penghayatan hati. ${ }^{83}$

Munculnya pandangan fiqh tentang jïhâd sebagai metode penyebaran Islam karena didasarkan atas kronologi dan teori penganuliran. Pertama, berdasarkan kronologi, semua penulis yang dipetakan di atas sepakat bahwa ayat-ayat perintah dakwah secara damai hanya merupakan fase awal. Para fuqahâ' menerima penjelasan dalam tafsir, terutama atas dasar penjelasan

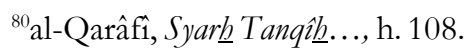

${ }^{81}$ al-Qarâfî, Syark $\underline{T}$ Tanqî….., h. 108.

${ }^{82}$ al-Bazdawî, Ushûl al-Bazdawî..., h. 305.

${ }^{83}$ Lihat Abdullah Yusuf Ali, The Holy Qur'an: Text, Translation, and Commentary (Beirût: Dâr al-'Arabîyah li al-Thibâ'ah wa al-Nashr wa al-Tawzî', 1968), h. 103. 
Ibn 'Abbâs, bahwa dakwah tersebut hanya berlaku di fase awal Islam di Makkah.

Kedua, ayat perintah memaafkan atas perlakuan buruk orang-orang kafir Makkah, ayat perintah tidak menghiraukan (tidak memusuhi) mereka, dan ayat perintah dakwah secara damai, yaitu dengan bikmah, nasihat yang baik, dan perdebatan dengan cara yang terbaik dianggap telah dianulir oleh ayat-ayat perang yang turun sesudahnya. Ayat-ayat yang umumnya yang dirujuk adalah "maka maafkanlah (mereka) dengan cara yang baik" (Q.15/54:85), "maka sampaikanlah secara terang-terangan segala apa yang diperintahkan dan berpalinglah dari orang-orang musyrik", (Q.15/54:94), dan "serulah kepada jalan Tuhanmu dengan bikmah, nasihat yang baik, dan bantahlah mereka dengan cara yang terbaik" (Q.16/70:125).

Pandangan yang tampak ekstrem dalam konteks ini dikemukakan oleh al-Kâsânî bahwa ayat pedang (Q.9/113:5) adalah rujukan kebolehan memerangi orang-orang kafir secara ofensif, meski sebelumnya dakwah tidak pernah disampaikan kepada mereka, karena ayat tersebut menganulir fase-fase awal, seperti larangan berperang pada bulan-bulan suci. ${ }^{84}$

Argumen penganuliran ini tampak dipengaruhi kuat oleh riwayatriwayat penganuliran ayat-ayat tersebut yang berkembang dalam tafsir, terutama yang berasal dari Ibn 'Abbâs, seperti melalui karya Abû 'Ubayd dan al-Baghdâdî maupun penafsiran-penafsiran Ibn 'Abbâs yang terpencar yang kemudian dikompilasi tafsir awal, seperti al-Tsabarî. Penganuliran ayat pemberian maaf atas perlakuan kasar orang-orang kafir Makkah terhadap Nabi (Q.5/112:13/ Q.3/89:159; Q.2/87:109), ayat perintah tidak menghiraukan mereka (Q.7/39:199), perintah dakwah dengan cara damai (Q.29/85:46), dan kebebasan beragama (Q.109/18:6) memiliki alur yang sama dengan penganuliran ayat-ayat semaknanya yang dikemukakan oleh para fuqahâ. Enam ayat (Q.15/54:94, Q.109/18:6, Q.24/102:54, Q.5/ 112:99, Q.6/55:68, dan Q.6/55:108) dari ayat-ayat yang dirujuk oleh alSyâfi'î merupakan ayat-ayat yang dikenal teranulir dalam literatur-literatur naskh. Dari urutan ayat-ayat yang disusun kita bisa membedakan tiga fase dakwah damai di Makkah: (1) fase awal ketika Nabi diperintahkan menyampaikan misi kenabian dan jaminan Tuhan akan perlindungan dari

\footnotetext{
${ }^{84}$ al-Kâsânî, Badâ'i' al-Shanâ'i'..., vol. 7, h. 100.
} 
perlakuan buruk orang-orang kafir Makkah, (2) fase ketika sudah terjadi hambatan dakwah, tapi tetap tidak ada perintah untuk berperang dan juga tidak ada perintah menjauhi mereka, (3) fase ketika ada perintah untuk menjauhi mereka. Momen-momen ini adalah apa yang sering dikutip oleh para mufassir sebagai "fase awal Islam" (fî bad al-Islâm) dari keterangan Ibn 'Abbâs. Pada fase kedua, al-Syâfi'î mencatat titik keputus-asaan dakwah Nabi dan pernyataan ayat bahwa mereka tidak akan beriman juga, hingga ditunjukkan mukjizat inderawi (b?issi) (Q.17/50:90-93, Q.14/72:97). ${ }^{85}$

Adanya penjelasan tentang keputus-asaan ini kemudian ditemukan juga pada penjelasan al-Kayâ al-Harâsî, seorang mufassir ayat-ayat hukum beraliran Syâfi'̂̂, yang dijadikannya sebagai titik-tolak penganuliran ayatayat damai. Momen ini, menurutnya, adalah momen ketika kaum muslim masih lemah, sedangkan penolakan dan penindasan terjadi semakin intensif. Keadaan mereka di Madinah lebih baik dan menjadi kekuatan seimbang. Perubahan ini yang menyebabkan ayat-ayat dakwah dengan cara damai dianggap tidak berlaku lagi. ${ }^{86}$

Dalam Tuhfat al-Muhtâj, al-Haytamî membantah pendapat al-Zarkasyî yang mengatakan bahwa jỉhâd adalah kewajiban sebagai sarana, bukan tujuan. Menurut al-Zarkasyî, mengemukakan argumen sebagai sarana lebih diutamakan daripada menggunakan kekuatan fisik, karena tujuannya adalah memberi hidayah. Kritik al-Haytamî pada dasarnya memuat empat hal. Pertama, pernyataan al-Zarkasyî bahwa tujuannya adalah untuk memberi hidayah, menurut al-Haytamî, menunjukkan bahwa jizyah tidak mesti bisa diterima ${ }^{87}$ Al-Haytamî dalam hal ini ingin menegaskan bahwa jizyah tidak bisa dianggap sebagai pengganti (alternatif), atau bahkan pengakuan kekufuran mereka. ${ }^{88} \mathrm{Hal}$ ini karena bagi kalangan ulama Syâfi'î, alasan jihâd adalah kufr. Kedua, menurutnya, penggunaan argumen dianggap tidak efektif, karena jarang sekali, bahkan mustahil, orang-orang kafir akan beriman dengan penjelasan argumen. Pernyataan ini, seperti halnya pada

\footnotetext{
${ }^{85}$ al-Syâfi'î, Abkâm al-Qur'ân..., vol. 2, h. 8-10.

${ }^{86}$ al-Kayâ al-Harâsî, A Alkeâm al-Qur'ân, vol. 3 (Beirût: Dâr al-Kutub al-'Ilmîyah, 1983), h. 163.

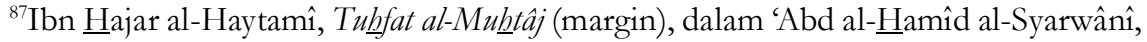
Hawâshî Tuhfat al-Muhtâj bi Syarb al-Minhâj..., vol. 9, h. 211.

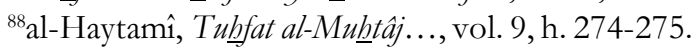


al-Syâfi'î dan al-Kayâ al-Harâsî, menunjukkan keputus-asaan dan dominasi logika kekuatan. Ketiga, seringnya perang pada masa Nabi, yaitu dua puluh tujuh ghazwah dan tiga puluh delapan sariyah. Perujukan ke "kuantitas" perang seperti ini, dengan mengabaikan latar belakang peristiwa sesungguhnya dan sejumlah perjanjian damai yang gagal, sering menjadi perujukan tidak utuh. Keempat, untuk menopang argumen ini, ia mengemukakan ayat-ayat jihâd yang turun dalam proses kronologis hingga berakhir pada fase akhir, di mana jihhâd menjadi kewajiban perang mutlak dengan mengacu kepada Q.9/113:36 dan Q.9/113:41 yang disebutnya sebagai ayat pedang. Dengan argumen ini, al-Haytamî berkesimpulan, "sepertinya jïhâd adalah tujuan, bukan sarana" (wa ka anna al-jïhâd maqshûd, lâ wasîlab). ${ }^{89}$

\section{Penutup}

Persoalan ayat pedang adalah persoalan klasik yang hingga kini tak tersentuh oleh penanganan intelektual. Padahal, persoalan ini berakibat panjang tidak hanya dalam disiplin 'ulum al-Qur'ân, melainkan juga dalam fiqh yang melahirkan pembenaran kekerasan terhadap non-muslim yang tidak bersalah. Pengaruh anomali berpikir ini masih sangat terasa yang tampak dari justifikasi-justifikasi yang melatarbelakangi aksi-aksi kekerasan, seperti pemboman di tanah air. M.A.S. Abdel Haleem pernah mengatakan bahwa ayat pedang hanyalah mitos yang diciptakan oleh kaum muslim sendiri yang muncul dari pemahaman yang tidak utuh terhadap ayat-ayat tertentu dalam Alquran..$^{90}$ Di samping itu, kekeliruan tersebut mucul dari penyimpulan yang keliru atas fakta-fakta sejarah perang masa Nabi, serta faktor-faktor sosio-historis-politis dan ideologis tertentu yang panjang dalam sejarah []

${ }^{89}$ al-Haytamî, Tubfat al-Mubtâj..., vol. 9, h. 211.

90"The Sword-Verse Myth (El mito del'versiculo de la espada)", dalam El Coran ayery boy (The Quran Yesterday and Today), ed. Peña Marín, Salvador, dan de Larramendi, Miguel Hernando (Cordoba: Berenice, 2008), h. 307-340. Artikel ini juga diterbitkan sebagai occasional paper 1 di Journal of Qur'anic Studies (JQS), 2007. 


\section{DAFTAR PUSTAKA}

Abdel Haleem, M.A.S. “The Sword-Verse Myth (El mito del'versiculo de la espada)", dalam El Coran ayer y hoy (The Quran Yesterday and Today), ed. Peña Marín, Salvador, dan de Larramendi, Miguel Hernando (Cordoba: Berenice, 2008), 307-340.

Al-Adnarawî, Ahmad bin Muhammad. Thabaqât al-Mufassirîn, vol. 2, ed. Sulaymân bin Shâlih al-Khizzî. Madinah: Maktbat al-'Ulûm wa alHikam, 1997.

Al-Albânî, Muhammad Nâshir al-Dîn. al-Silsilah al-Dha'îfah, vol. 6. Riyâdh: Maktabat al-Ma'ârif, t.th.

Ali, Abdullah Yusuf. The Holy Qur'an: Text, Translation, and Commentary. Beirut: Dâr al-'Arabîyah li al-Thibâ'ah wa al-Nashr wa al-Tawzî', 1968.

Al-Anshârî, Zakarîyâ. Asnâ al-Mathâlib, vol. 4, ed. Muhammad Tâmir. Beirût: Dâr al-Kutub al-'Ilmîyah, 2000.

Anwarul Haqq. Abrogation in the Koran. India: Methodist Publishing House, 1926.

Al-'Asqalânî, Ibn Hajar. al-Mu'jam al-Mufahras (Tajrîd Asânîd al-Kutub alMasyhûrah wa al-Ajzấ al-Mantsûrah). Beirût: Mu'assasat al-Risâlah, $1418 \mathrm{H} / 1998 \mathrm{M}$.

. al-Nukat 'alâ Kitâb Ibn al-Shalâh. Beirût: Dâr al-Kutub al-'Ilmîyah, 1994.

. Tahdzî̉b al-Tahdzî̉, vol. 3, ed. suntingan Ibrâhîm al-Zaybak dan 'Âdil Mursyid. Beirût: Mu`assasat al-Risâlah, t.th.

Al-Baghdâdî, 'Abd al-Qâhir. al-Nâsikh wa al-Mansûkh, ed. Hilmî Kâmil As'ad 'Abd al-Hâdî. Aman: Dâr al-'Adawî, t.th.

Bar-Asher, Me'ir Mikha'el. Scripture and Exegesis in Early Imâmî-Shiism. Leiden: Brill, 1999. 
Al-Birrî, 'Abdullâh Khûrsyîd. al-Qur ân wa Ulûmuh fî̀ Mishr (20 H - 358 H). Mesir: Dâr al-Ma'ârif, t.th.

Al-Dzahabî, Munhammad ㅂusayn. al-Tafsîr wa al-Mufassirûn, vol. 1. Cairo: Maktabat Wahbah, 2000.

Al-Dzahabî, Syams al-Dîn. Siyar A'âm al-Nubalâ', vol. 13, ed. Syu'ayb alArna'ûth dan 'Alî Abû Zayd. Beirût: Mu'assasat al-Risâlah, 1983/1403.

Al-Dhahhâk. Tafsîr al-Dhahhâke, vol. 2, kompilasi Syukrî Ahmad al-Zâwînî. Beirût: Dâr al-Salâm, 1419 H/ 1999 M.

Al-Fârisî, Ibn Khuzaymah. al-Mûjaz fì al-Nâsikh wa al-Mansûkh. Cairo: alMaktabah al-Azharîyah li al-Turâts, t.th.

Gilliot, Claude. "The Beginnings of Qur'ânic Exegesis", dalam Andrew Rippin (ed.). The Qur'an: Formative Interpretation. Great Britain: Ashagate, 1999.

Al-Harâsî, al-Kayâ. A $\underline{h} k a ̂ m$ al-Qurân, vol. 3. Beirût: Dâr al-Kutub al'Ilmîyah, 1983.

Hibatullâh ibn Salâmah. al-Nâsikh wa al-Mansûkh, margin al-Wah?idî, Asbâb al-Nuqûl. Cairo: Maktabat al-Mutannabî, t.th.

—. al-Nâsikh, ed. Zuhayr al-Shâwîs dan Muhammad Kan'ân. Beirût: al-Maktab al-Islâmî, 1404 H.

Ibn 'Âdil al-Dimasyqî. al-Lubâb fî̀ Ulûm al-Kitâh, vol. 10, ed. Syaykh 'Âdil Ahmad 'Abd al-Mawjûd. Beirût: Dâr al-Kutub al-'Ilmîyah, 1998 M/ $1419 \mathrm{H}$.

Ibn al-'Arabî. al-Nâsikh wa al-Mansûkh fí al-Qurân al-Karîm, anotasi al-Syaykh Zakarîyâ 'Umayrât. Beirût: Dâr al-Kutub al-'Ilmîyah, 2006.

Ibn al-Bârizî. Nâsikh al-Qur'ân al-'Azîn wa Mansûkhuh, dalam Silsilat Kutub al-Nâsikh wa al-Mansûkh, ed. Hâtim Shâlih al-Dhâmin. Beirut: Mu'assasat al-Risâlah, 1998.

Ibn al-Jawzî. Nawâsikh al-Qur'ân. Beirût: Dâr al-Kutub al-'Ilmîyah, t.th. 
Ibn Katsîr. Tafsîr Ibn Katsîr, vol. 2. Beirût: Dâr al-Fikr, 1986.

Ibn Manzhûr. Lisân al-'Arab, vol. 12. Beirût: Dâr Shâdir, t.th.

Al-Lâhim, Sulaymân bin Ibrâhîm bin 'Abdullâh. al-Nâsikh wa al-Mansûkh fî̀ Kitâb Allâh 'Azza wa Jalla wa Ikbtilâf al-Ulamâ' fì Drâlika Ta' lîf Abî

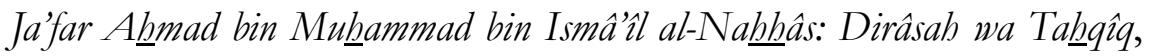
vol. 1. Beirût: Mu`assasat al-Risâlah, 1991.

Al-Majlisî, Muhammad Bâqir. Bihbâr al-Anwâr al-jâmi'ah li Durar Akhbâr alA'immah al-Athhâr, vol. 97. Beirût: Mu'assasat al-Wafâ‘, 1983.

Al-Mizzî. Tahdzî̉ al-Kamâl, vol. 24, ed. Basysyâr 'Awwâd Ma'rûf. Beirut: Mu`ssasat al-Risâlah, 1982.

Al-Nawawî. Rawdhat al-Thâlibîn, vol. 10. Beirût: al-Maktab al-Islâmî, 1405 $\mathrm{H}$.

Qatâdah. Kitâb al-Nâsikeh wa al-Mansûkkh fí Kitâb Allâh Ta'âlâ, dalam Silsilah Kutub al-Nâsikh wa al-Mansûkh, ed. Hâatim Shâlih al-Dhâmin. Beirût: Mu'assasat al-Risâlah, 1998.

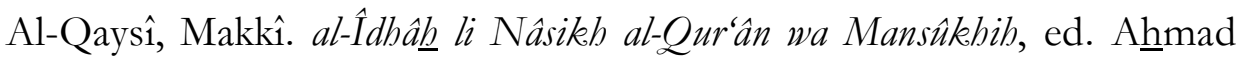
Hasan Farhât. Jeddah: Dâr al-Manârah, 1986.

Al-Qurthubî. al-Jâmi' li A $\underline{b k a ̂ m}$ al-Qur'ân, vol. 8. Beirût: Mu'assasat alRisâlah, 2006.

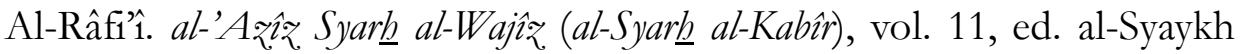
'Alî Muhammad Mu'awwadh dan al-Syaykh 'Âdil Aḥmad 'Abd alMawjûd. Beirût: Dâr al-Kutub al-'Ilmîyah, 1997 M/ 1417 H.

Al-Ramlî. Nihâyat al-Mubtâj, vol. 8. Beirût: Dâr al-Fikr, 1984.

Al-Râzî, Ibn Abî Hâatim. Kitâb al-Jarh wa al-Ta'dûl, vol. 1. Beirût: Dâr alFikr, t.th.

- Tafsîr al-Qur'ân al-'Az̧hìm, Musnadan 'an al-Rasûl Shallâ Allâh 'Alayh wa Sallam wa al-Shabâabah wa al-Thâbi'în, vol. 6, ed. As'ad Muhammad al-Thayyib. Riyâdh: Maktabat Nizâr Mushthafâ al-Bâz, 1997/1417. 
Al-Sabt, Khâlid 'Utsmân. Qawầid al-Tafsîr: Jam'an wa Dirâsatan, vol. 2. Mesir: Dâr Ibn 'Affân, 1421 H.

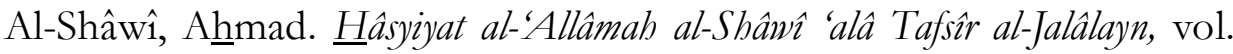
2. Beirut: Dâr al-Fikr, 1993.

Schleifer, S. Abdullah. "Jihâd and Traditional Islamic Consciousness", dalam The Islamic Quarterly, vol. 27, no. 4 (1983), 192-193.

Al-Syâfi'î. al-Umm, vol. 7. Cairo: Kitâb al-Sha’b, 1967.

Al-Syarbînî, Muhammad bin Aḥmad. Tafsîr al-Sirâj al-Munîr, vol. 1. Beirût: Dâr al-Kutub al-'Ilmîyah, t.th.

Shu'lah. Shafwat al-Râsikh fî Tlm al-Mansûkkh wa al-Nâsikh, ed. Muhammad Ibrâhîm 'Abd al-Rahmân Fâris. Ayn Syams: Maktabat al-Tsaqâfah al-Dînîyah, 1995.

Al-Suyûthî, Jalâl al-Dîn dan Jalâl al-Dîn al-Mahallî. Tafsîr al-Qur'ân al-'Az̧hîm (Tafsîr al-Jalâlayn), vol. 1. Semarang: Toha Putra, t.th.

Al-Suyûthî, Jalâl al-Dîn. al-Itqân fì 'Ulùm al-Qur ân, vol. 2. Beirût: Dâr alFikr, t.th.

—. al-Taḅbîr fî̀ Tlm al-Tafsîr. Cairo: Dâr al-Manâr, 1986.

—. Mu'tarak al-Aqrân fí I'jâz al-Qur'ân, vol. 1. Beirût: Dâr al-Fikr al'Arabî, t.th.

Al-Tsa'labî, Ibrâhîm. al-Kasyf wa al-Bayân, vol. 5, ed. Abû Muhammad bin 'Âsyûr. Beirût: Dâr Ihyâ’ al-Turâts al-'Arabî, 2002 M/ 1422 H.

Wansbrough. Quranic Studies: Sources and Methods of Scriptural Interpretation. Oxford: Oxford University Press, 1977.

Al-Zarqâ, Syaykh A $\underline{h m a d}$ bin al-Syaykh Muhammad. Syark al-Qawầid alFiqhîyah, ed. 'Abd al-Sattâr Abû Ghuddah. Damaskus: Dâr al-Qalam, 1996.

Al-Zubaydî, Murtadhâ. Tâj al-'Arûs, vol. 1. T.tp: Dâr al-Hidâyah, t.th. 